\title{
LA EXPLICACIÓN A LA PINTURA DEL IMPRESIONISMO
}

\author{
Héctor Bernal Mora \\ Universidad de Guadalajara, México
}

Resumen: El presente artículo explica la pintura del Impresionismo en el contexto de la Teoría del Carácter de Producción, una orientación psicológica involuntaria e inconsciente que sirve para trabajar y que determina las peculiaridades de la existencia social del individuo; es decir, sus manifestaciones artísticas, religiosas, morales, jurídicas, filosóficas, y sus estructuras de carácter, costumbres y actitudes. El impresionismo es el movimiento pictórico francés que marcó el inicio de la modernidad en el arte, de ahí su trascendencia. Todas sus características, como su temática, su estilo estético, la psicología de los personajes; así como la subjetividad del pintor impresionista se explican mediante esta teoría. En el mismo marco conceptual se pretende explicar los movimientos postimpresionista y neoimpresionista a que dio paso el Impresionismo. La emotividad orientada en el Carácter de Producción de estos movimientos artísticos en tanto estilo-temática, se definen como inestabilidad-alegría, en el Impresionismo; estabilidad-desencanto/evasión/fuga, en el postimpresionismo; y estabilidad/neutralizacióndesencanto/evasión, en el neoimpresionismo.

Palabras clave: carácter de producción, explicación, impresionismo, postimpresionismo, neoimpresionismo

\section{Explaining Impressinist Painting}

Abstract: This article explains Impressionist painting in the context of the Theory of the Character of Production, an involuntary and unconscious psychological orientation useful to work which determines the peculiarities of the social existence of man; this is, his artistic, religious, moral, legal and philosophical manifestations, together with his structures of character, habits and attitudes. Impressionism is the French painting movement that set the basis for the modernity of art. All its characteristics, themes aesthetic style, psychology of characters, together with the subjective nature of the impressionist artist can be explained using this theory. The purpose is to explain the postimpressionism and neoimpressionism movements that came after Impressionism; emotion geared towards the Character of Production of these artistic movements is defined as instability-joy in Impressionism; stability-deception/evasion in postimpressionism; and, stability/neutralization-deception/evasion in neoimpressionism.

Keywords: character of production, explanation, impressionism, postimpressionism, neoimpressionism

Una Mañana a uno de nosotros se le olvidó el negro, y ese fue el nacimiento el impresionismo.

Pierre-Auguste Renoir

No hace mucho tiempo, la tierra estaba poblada por dos mil millones de habitantes, es decir, quinientos millones de hombres y mil quinientos millones de indígenas. Los primeros disponían del Verbo, los otros lo tomaban prestado.

Jean-Paul Sartre 


\section{Introducción}

¿Por qué las condiciones socioeconómicas devienen arte? ¿Por qué, por ejemplo, la pintura del impresionismo? ¿Por qué surge? ¿Por qué te gusta? ¿Por qué surge en Francia? ¿Por qué se expande por todo el mundo? ¿Por qué la temática del impresionismo? ¿Por qué la psicología de los personajes de la pintura impresionista? ¿Por qué la subjetividad del pintor impresionista? ¿Por qué su estilo estético? ¿Por qué la tendencia de la pintura impresionista a destruir la forma? ¿Por qué su aspecto desdibujado y esquemático como una fotografía primitiva? ¿Por qué el pintor impresionista no le puso el contorno a la figura? ¿Se le olvidó? ¿No tenía negro? ¿Le gustó? ¿Por qué le gustó? ¿Te atrae? ¿Por qué te atrae? ¿Por qué las distintas corrientes artísticas de la cultura humana? ¿Por qué el arte universal? ¿Por qué las manifestaciones artísticas de los distintos grupos sociales? ¿Por qué las manifestaciones de tu grupo social? ¿Por qué tu cultura? ¿Por qué te gusta lo que te gusta? ¿Por qué la cultura del hombre?

El objetivo del presente artículo es explicar la pintura del impresionismo estableciendo nexos causales entre el modo de producción de Francia en la década final del Siglo XIX, que se desvanecía, y dicho movimiento. Nexo causal significa extraer u obtener de las características de un sector de la realidad las particularidades de otro, características que hacen inteligible dicho movimiento artístico, encontrar su sentido o razón de ser (Ver pintura 1. Estilo impresionista).

\section{Pintura 1}

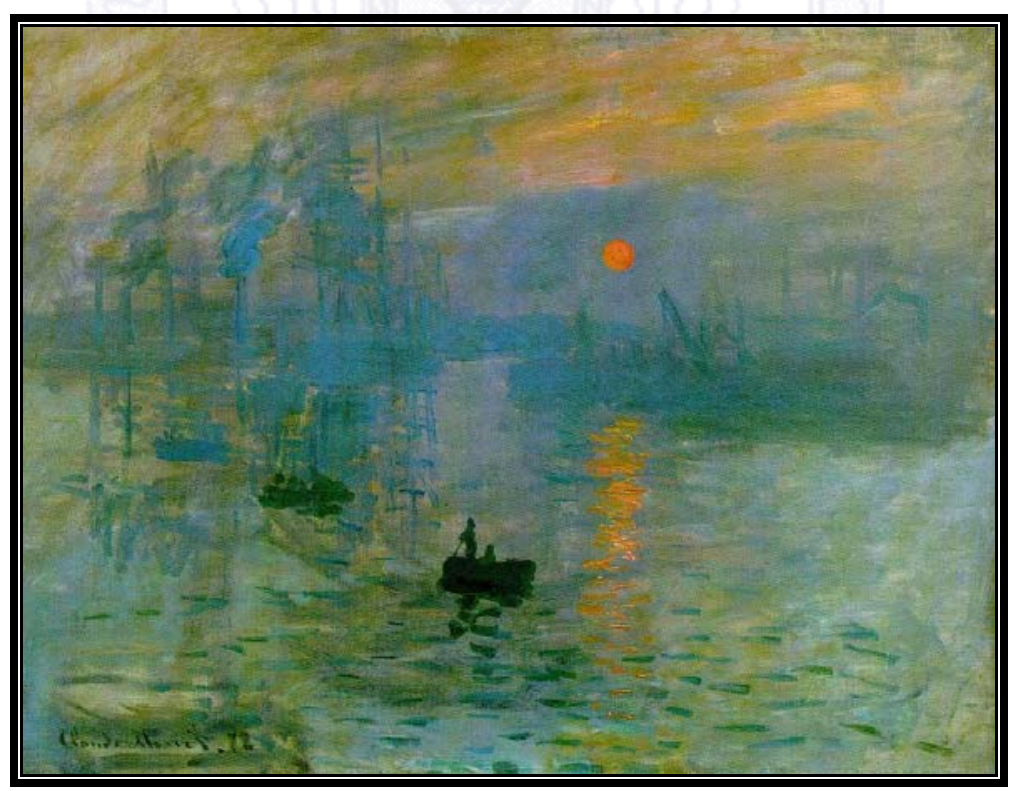

Autor: Claude Monet

Obra: Impresión, 1872 


\section{Justificación}

Es fácil saber por qué estas preguntas que planteo no tienen, hasta antes de la teoría del Carácter de Producción, una respuesta. En la literatura nunca se plantearon, no han merecido la atención de los investigadores, las desechan consciente 0 inconscientemente al considerarlas inasibles al entendimiento. Esta teoría las responde, contesta preguntas no formuladas, de ahí su excentricidad teórica.

El Carácter de Producción es una teoría propia, publicada en la Revista Universidad de Guadalajara. En ella sostengo que:

Cuando trabajamos, adquirimos sin darnos cuenta, estructuras psíquicas que nos permiten laborar; sin embargo, estas mismas estructuras, al ser de naturaleza inconsciente, determinan la totalidad de nuestra vida. Éstas son el resultado de una orientación psicológica inconsciente que surge al trabajar y constituyen lo que llamo "Carácter de Producción". El Carácter de Producción del esclavo, por ejemplo, es distinto del que tiene el ejecutivo moderno, no obstante, surgen mediante el mismo mecanismo, es decir, como una necesidad inconsciente de adaptación al trabajo. (1)

Por tanto el Carácter de Producción

...determina las peculiaridades de la existencia social del individuo, es decir, sus manifestaciones artísticas, éticas, religiosas, morales, jurídicas, filosóficas y sus estructuras de carácter, costumbres y actitudes. (2)

\section{Desarrollo}

En el presente artículo explico la pintura del Impresionismo valiéndome de esta teoría. Para explicar su origen divido la pintura del impresionismo en varias características que la distinguen, no sin antes hacer notar que esta división es artificial, ya que el fenómeno es unitario.

\section{La explicación de la temática de la pintura del Impresionismo.}

El impresionismo es un movimiento realista. Courbet, perteneciente al realismo, movimiento antecesor del impresionismo, afirmaba que:

...en el realismo sólo la realidad observada por el artista podía ser el punto de partida y el criterio de valoración de un cuadro. Por ello, erradicaba del realismo los cuadros de historias, los temas mitológicos y religiosos, y todo aquello que tenía origen sólo en la imaginación. (3) (Ver pintura 2. Estilo realista) 


\section{Pintura 2}

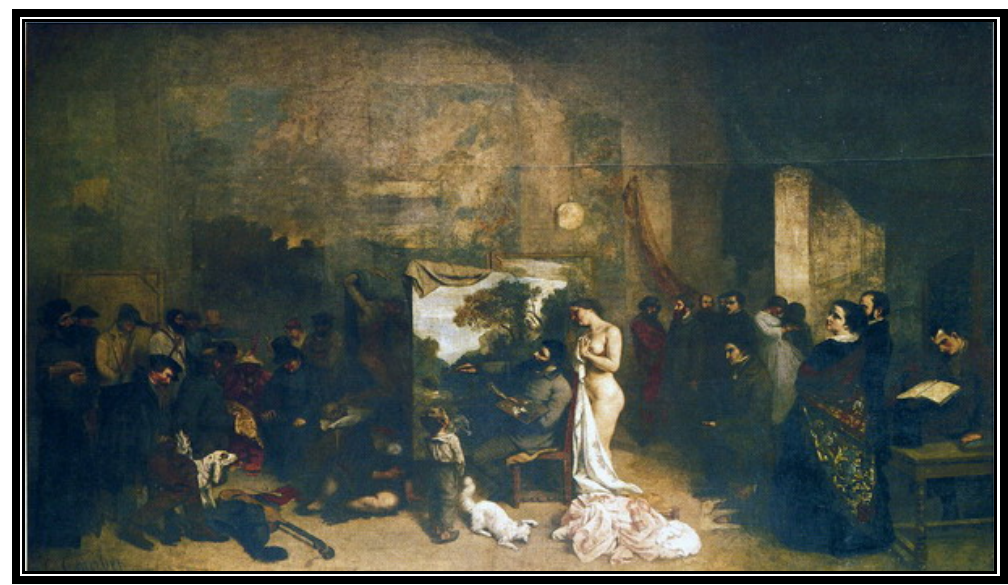

Autor: Gustave Courbet

Obra: El atelier del pintor, 1854-55

El impresionismo es una reacción contra el clasicismo, a saber:

La tradición más importante era el clasicismo, es decir, el reconocimiento del valor paradigmático de la Antigüedad griega y el arte romano, por encima de otra escuela o tendencia. Clasicismo significa reconocer la autoridad del lenguaje formal y la selección de motivos de un gran arte del pasado, con su consiguiente imitación. Ello suponía la convicción de que las obras de arte debían ser bellas, nobles y pedagógicas, y que existían criterios infalibles para valorar la belleza, así como reglas para su configuración. La interpretación clasicista del arte pone la idea por encima de la realidad: basándose en la idea de la perfección que le había sido inculcada, el artista debía corregir los azares y las imperfecciones de la realidad mediante el estudio de sus figuras y motivos. (4) (Ver pintura 3. Estilo clasicista)

Pintura 3

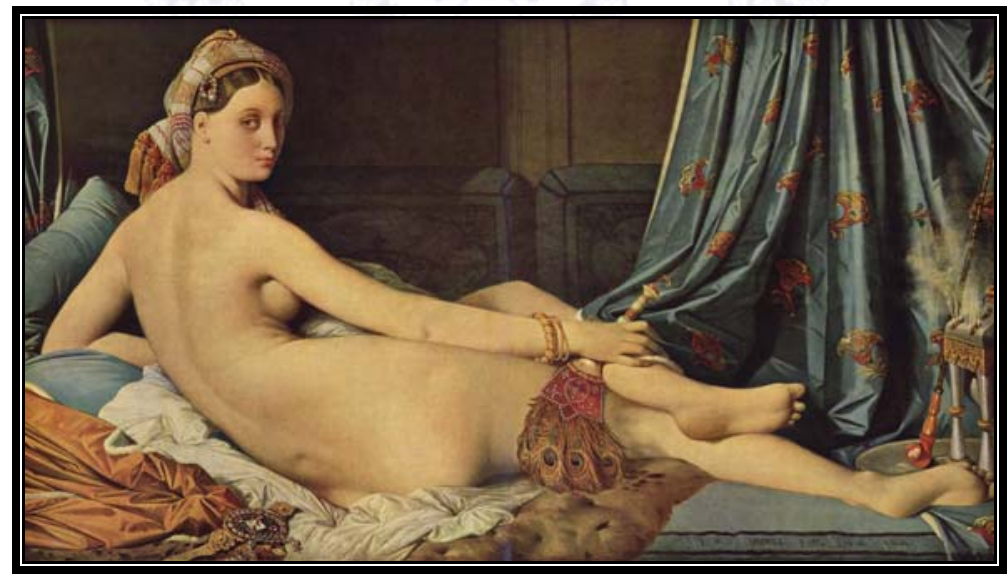

Autor: Jean Auguste Dominique Ingres Obra: La gran Odalisca, 1814 


\section{A) La explicación del realismo en la temática de la pintura del impresionismo}

En la teoría del Carácter de Producción la cultura humana es una orientación inconsciente del carácter que sirve para trabajar. Para poder explicar su temática, como todas sus características, tenemos que determinar el entorno económico de la Francia de finales del siglo XIX, cuando nace el impresionismo, y con anterioridad en el siglo XVII en Europa, en concreto en Inglaterra, el entorno económico del realismo, movimiento al que pertenece.

Con relación al realismo Inglés y su entorno, sabemos que

Desde el siglo XVII, los pintores ingleses y sus clientes manifestaban una decidida preferencia por los paisajes, que en la teoría clasicista imperante ocupaban un rango inferior. A raíz del desarrollo especial de su economía y su sociedad, Inglaterra había sido el lugar de nacimiento de una nueva tendencia en la representación de paisajes: los jardines. A partir de la mitad del siglo XVIII, los aficionados y pintores de gustos modernos del continente europeo importaron los principios de esos jardines ingleses con la misma avidez que otras novedades económicas, técnico-prácticas e intelectuales surgidas con la revolución Industrial. (5)

Y con relación al caso concreto de Francia, donde nace el impresionismo:

Al carácter ejemplar del absolutismo francés, encarnado por el Rey Sol Luís XIV se contrapuso mas tarde la Revolución Francesa de 1789 , que en su condición de guía fue seguida de profundos movimientos populares a nivel mundial. El desarrollo de la sociedad burguesa del siglo XIX, incluyendo su impronta cultural, se consumó en Francia de una manera más consecuente, significativa y prematura que en otros países. Para la vida artística en general, y en especial para el sistema de exposiciones, el comercio del arte y la definición de gustos y tendencias, París era la capital del siglo XIX, pese al hecho de que Inglaterra, gracias a su capacidad financiera y de producción, fuera considerada el taller del mundo. (6)

No es casual que el realismo y el impresionismo nacieran en Europa, en concreto Inglaterra y Francia, lugares del nacimiento del capitalismo moderno. El efecto psicológico del nacimiento del libre mercado capitalista en el Carácter de Producción, que el hombre acepta y disfruta porque lo libera del feudalismo, es situar al hombre en lo terrenal, lo real, de ahí el realismo de la temática de estos movimientos artísticos. El mercado es real así nos orienta, tan lo es que de él depende nuestra suerte aquí en la tierra. El fruto del trabajo ya no se entrega al señor feudal, no tiene un destinatario preestablecido, la mercancía del mercado capitalista permanentemente está en búsqueda de su destinatario, su real destinatario. Tampoco es una economía feudal de subsistencia sin mas atributo que la supervivencia, orientó al hombre en la vida después de la vida, en dios, representación psicológica inconsciente del rey y del señor feudal, destinatario de la economía feudal. Por el contrario la lógica del capitalismo es el acaparamiento, la lógica del capital es crecer terrenalmente, el mercado capitalista te toma, te sitúa, te ubica en el aquí y ahora. Te exige, si no entras en su lógica te destruye, no vendes, no te vendes, acabas en la ruina o desempleado. La oferta y la demanda capitalista es real le pone precio a nuestro trabajo y producto. Los orientados, tanto pintores preimpresionistas realistas como los impresionistas, ya no prefieren pintar escenas mitológicas, 
pastorales o religiosas que tiene su origen sólo en la imaginación, prefieren pintar escenas de la vida cotidiana. "Yo pinto lo que veo y no lo que otros quieren que vea", decía Manet, su inspiración es la realidad.

\section{B) La explicación de los motivos/temática de la pintura del impresionismo}

El naciente capitalismo liberó al hombre de la formación socioeconómica que le precedió: el feudalismo. El hombre lo vive en el Carácter de Producción como un movimiento alegre y feliz, el motivo de la pintura del impresionismo: “...refleja la superficie llena de colorido de la vida, intenta reproducir la belleza de la apariencia superficial tal como se ve en las luces cambiantes y pretende captar el encanto del momento". (7)

Por consiguiente...

Constituía una protesta contra el polvoriento arte de gabinete imperante, con sus majestuosos temas históricos y mitológicos, vertidos generalmente con colores oscuros y terrosos y una iluminación arbitraria. (8)

La libertad del individuo en los albores del capitalismo llevó a la libertad de motivos y del color una orientación inconsciente:

En el trabajo de los impresionistas y de sus sucesores la pintura volvió de nuevo a sus fuentes originales: el color y la forma puros; se liberó de cualquier referencia literaria y alegórica. (9)

El pintor impresionista pinta alegre escenas al aire libre, representación inconsciente de su libertad, con motivos de paisajes y flores, mucho color y luz. Monet pinta:

...numerosos cuadros con una auténtica inundación de flores o arbustos floridos. Las resplandecientes aguas del Sena o sus afluentes bajo el cielo azul, con blancas nubes o alegres botes de remos sobre las olas, permitían una aplicación del color desenvuelta y pastosa. (10) (Ver pinturas 4 y 5) 


\section{Pintura 4}

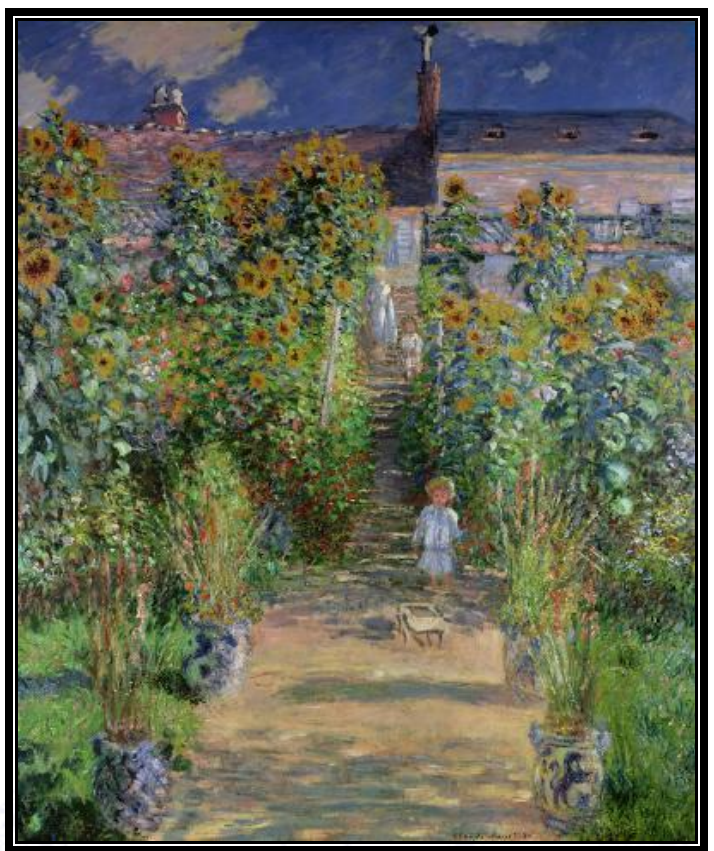

Autor: Claude Monet

Obra: El jardín de Monet en Vètheuil, 1881

\section{Pintura 5}

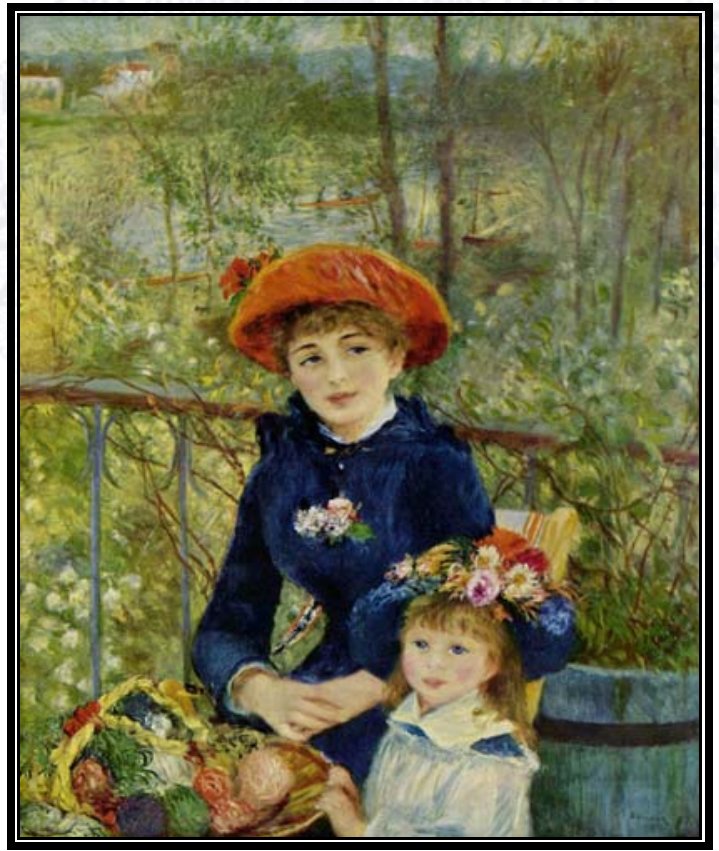

Autor: Pierre-Auguste Renoir Obra: En la terraza, 1881

Liberado el nuevo hombre disfruta su nuevo mundo. Así...

Los amantes sentían una verdadera fascinación por el nuevo París, ...seguían con mirada afectuosa la interminable cinta ancha y gris de las aceras, con sus bancos, sus abigarradas columnas anunciadoras y sus árboles. Esa limpia 
acera que se alargaba hasta el horizonte, haciéndose cada vez mas estrecha hasta desembocar en un espacio vacío de forma cuadrada...las multitudes que acudían en masa, con el ruido de sus zapatos y su vocerío, los colmaban de una dicha pura e incondicional, con una sensación de excelencia de la vida callejera. (11)

Orgulloso y fascinado de su nuevo mundo, al pintor impresionista lo inspiran sus motivos. Con relación a un cuadro de Guillaumin:

Poderosas columnas de humo surgen de las chimeneas de las fábricas de Ivry, un suburbio de París, como si fueran banderas triunfantes en el cielo vespertino de tonalidades rojas y doradas. (12) (Ver pintura 6)

\section{Pintura 6}

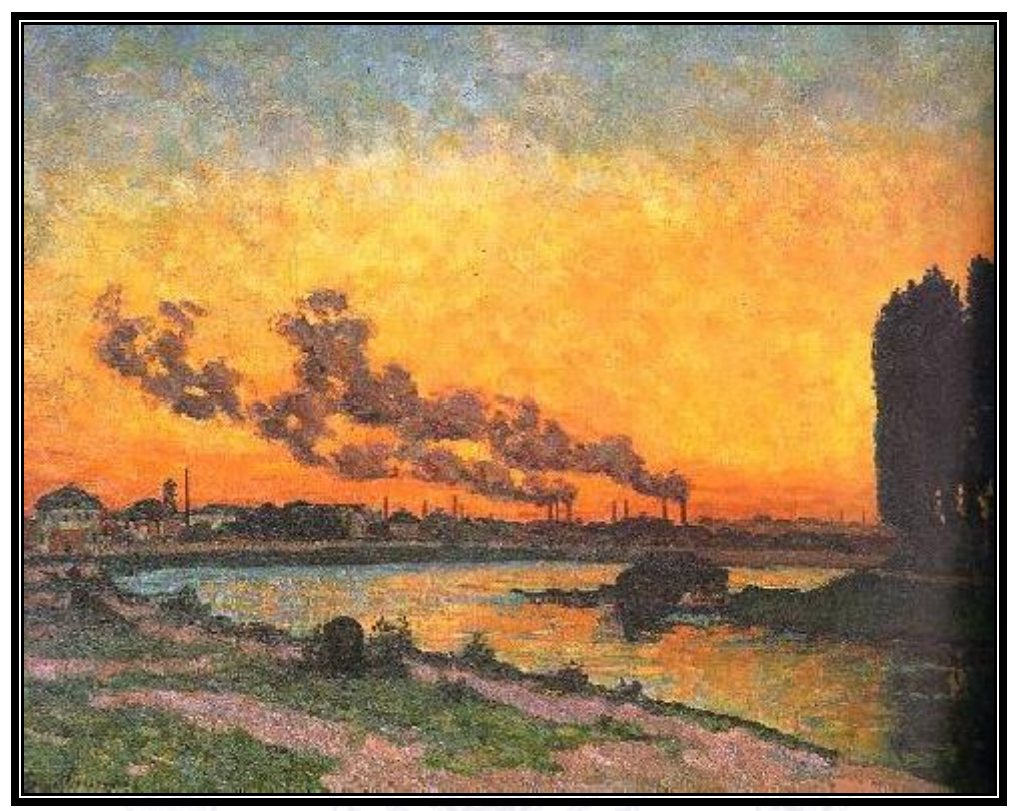

Autor: Armand Guillaumin

Obra: Puesta del sol en Ivry, 1873

Y con relación a un cuadro de Monet.

El movimiento y la aparición masiva de seres humanos que no pueden ser identificados como individuos, sumandos a la fascinación atmosférica de un día invernal en la época de carnaval, sirvieron a Monet de estímulo para realizar dos pinturas del Boulevard des Capucines. ....El observador cree realiente oír los caóticos ruidos ocasionados por los paseantes, las conversaciones, el rodar de los coches y el trote de los caballos. El artista retiene así como por arte de magia, una realidad agitada y en constante transformación. (13) (Ver pintura 7) 


\section{Pintura 7}

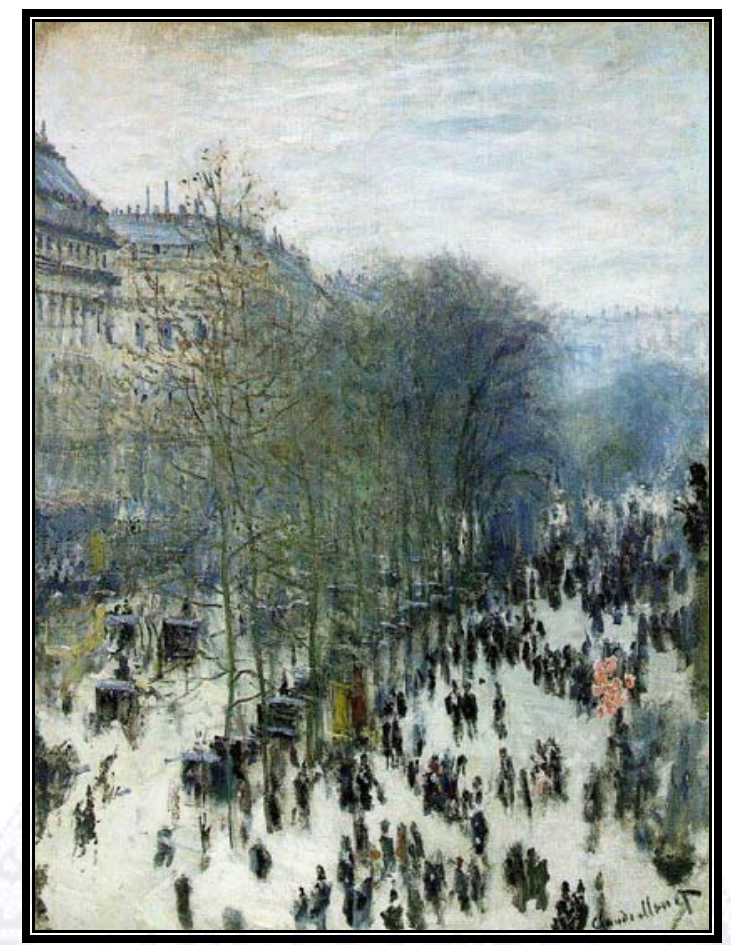

Autor: Claude Monet

Obra: El Boulevard des Capucines, 1873

El mercado capitalista, la libre oferta y demanda, su ritmo fugaz, también son los motivos orientados del pintor. Manet "...solía dibujar una pequeñez, un perfil, un sombrero, en pocas palabras, una impresión fugaz". (14)

\section{Edgar Degas...}

...elegía una postura diferente para cada retrato. Casi siempre captaba un determinado momento, relativamente fugaz, en el que se reflejaba una inquietud interior o una indecisión de la persona con respecto al entorno o a su propia realidad. (15) (Ver pintura 8) 
Pintura 8

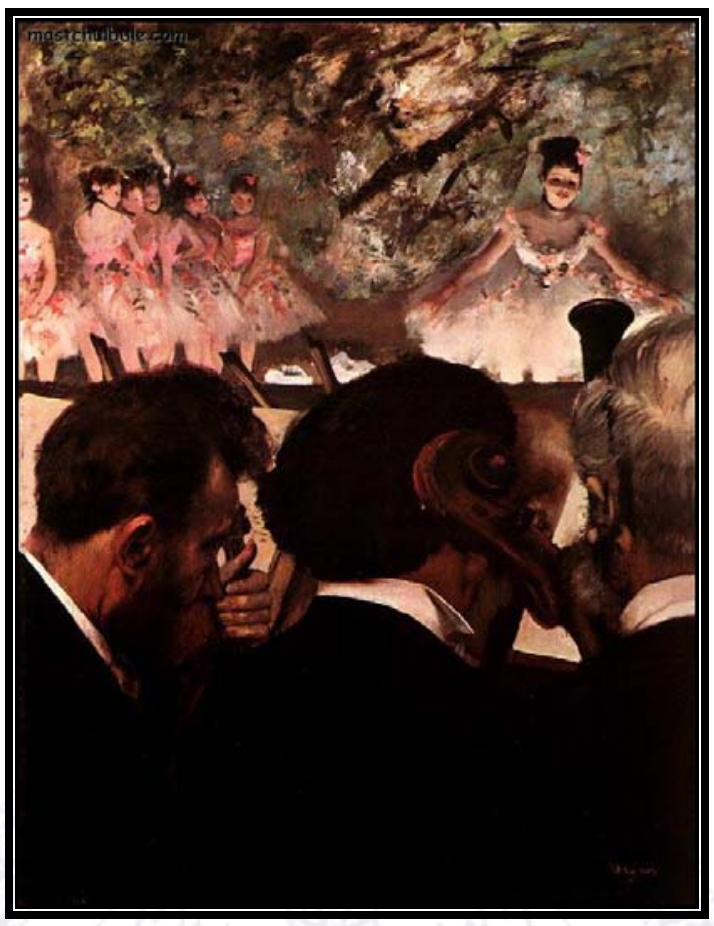

Autor: Edgar Degas

Obra: Músicos en la orquesta, 1870-71

La historia del impresionismo es mi sustento. El realismo como tendencia pictórica tuvo que haber iniciado, si la tesis que sostengo del Carácter de Producción es cierta, en los albores del mercado capitalista. Así fue, inició en el siglo XVII. El impresionismo, movimiento realista, al ser orientación, tuvo que ser un arte metropolitano, lugar del mercado capitalista. Así fue nace en esencia en una gran metrópoli, como París. Tuvo que ser un arte de aceptación de la sociedad, la reacción al inicio del capitalismo, liberador del feudalismo. Así fue, el impresionismo no fue un movimiento crítico. "Ninguno de ellos podía recibir el calificativo de revolucionario social o luchador de las barricadas". (16)

La historia es mi sustento. Si la tesis que sostengo es cierta, el impresionismo tuvo que ser un movimiento alegre, al ser el Carácter de Producción del hombre liberado. Lo fue en los lienzos que forman su realidad. No sólo eso, además de la temática de la pintura del impresionismo todas sus restantes características como su estilo estético, la psicología de los personajes, así como la subjetividad del pintor impresionista tienen que poder explicarse mediante el mismo mecanismo. Para finalizar, si la tesis que sostengo es cierta, el postimpresionismo y el neoimpresionismo son, como en la historia, reacción a su vez de la reacción, interpretaciones de la interpretación al inicio del mercado capitalista y su efecto psicológico en la sociedad, en el Carácter de Producción, una orientación involuntaria e inconsciente que sirve para trabajar. 


\section{La explicación del estilo estético de la pintura del impresionismo}

Respondamos de una vez las preguntas medulares, aquellas que distinguen al impresionismo como movimiento pictórico de todo lo precedente, marcando el inicio de la modernidad en el arte. ¿Por qué el pintor impresionista no le puso el contorno a la figura? ¿Por qué su tendencia a destruir la forma? ¿Por qué las líneas inestables del impresionismo?

Si la cultura del hombre es una orientación inconsciente del carácter, ¿qué sucedía en la economía que motivó que el pintor no le pusiera el contorno a la figura?

Nos encontramos en los albores del capitalismo. Las estructuras sociales se conmovían alterando las formas de percepción del hombre, su orientación. Parecía como si se moviera lo antes estable, la sociedad vibraba, las líneas que definen el lugar del hombre en la economía se diluían. De ahora en adelante cada quien buscaría libre su espacio en la producción.

Era la oferta y la demanda capitalista, la locura del capital cimbraba al hombre y su mundo. Una mañana Manet pintaba El Almuerzo sobre la hierba (Nota 1) (Ver pintura 9), pero ya no le puso el contorno a la figura.

\section{Pintura 9}

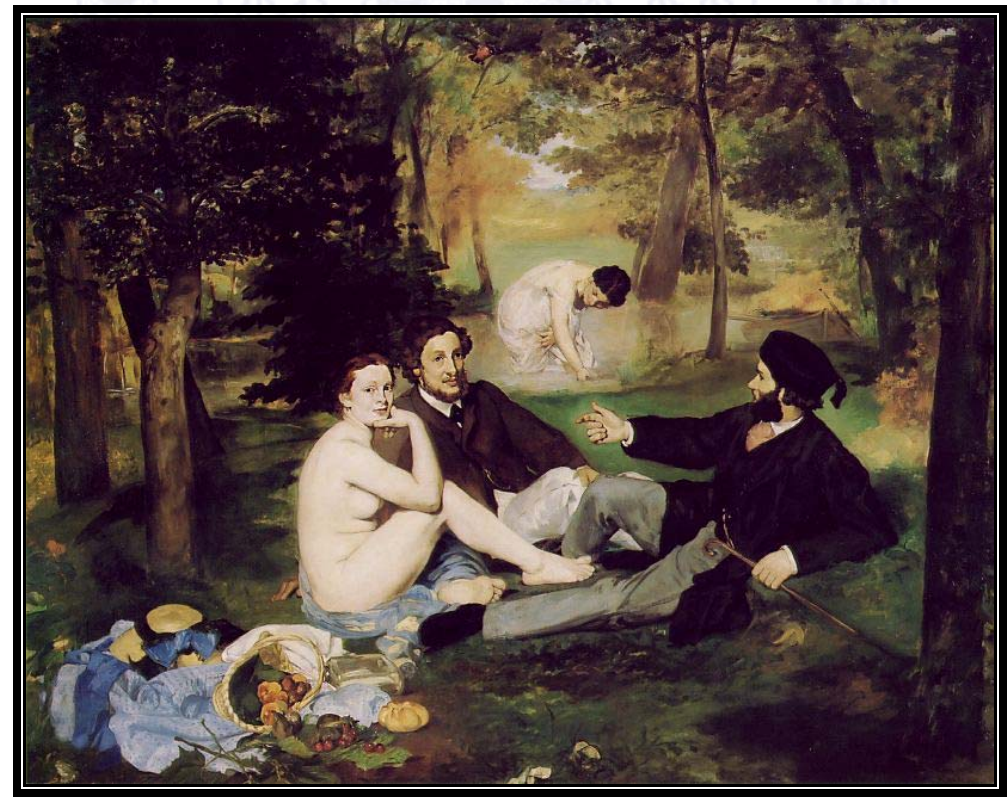

Autor: Edouard Manet

Obra: El almuerzo sobre la hierba, 1863

También como él y su mundo social, conmovidos se cimbraron, vibraron, se desestabilizaron. Había nacido el impresionismo, se desfiguró la figura. Así interpreta un genio el movimiento de la producción, las líneas delimitativas de la figura del lienzo impresionista se perdieron como se perdió el lugar estable del hombre en la economía, las líneas de su vida productiva. El libre mercado capitalista nos había regalado un tesoro estético para deleite del hombre y, tú, lector tienes ahora el deleite de entender lo sucedido ya hace mas de un siglo: es el Carácter de Producción, una orientación psicológica inconsciente. 
Los impresionistas, inconscientemente orientados, se pintaron en sus lienzos a sí mismos, felizmente liberados; pero víctimas de los nuevos engranes o desengranes del capital que incontrolable los "esfumaba".

Los impresionistas "...llevaron la disolución de la forma tradicional hasta la creación de un velo atmosférico y brillante tras el cual los objetos se esfumaban, anunciando un arte no objetivo". (17)

El naciente capitalismo no sólo desestabilizó la forma creando el estilo propio del impresionismo, también el cuadro como composición se desestabilizó cuando menos en algunos autores.

Los cuadros de Renoir y Monet no eran anecdóticos. Plasmaban la escena con composiciones inestables que quedaban abiertas a los lados y en las cuales parecían tambalearse los botes y los travesaños. Su manera de pintar, que operaba con manchas de color rápidas e intensas, se adecuaba a la ruidosa turbulencia de una divertida multitud y al juego de los coloridos reflejos de luz sobre la agitada superficie del agua. (18) (Ver pintura 10)

\section{Pintura 10}

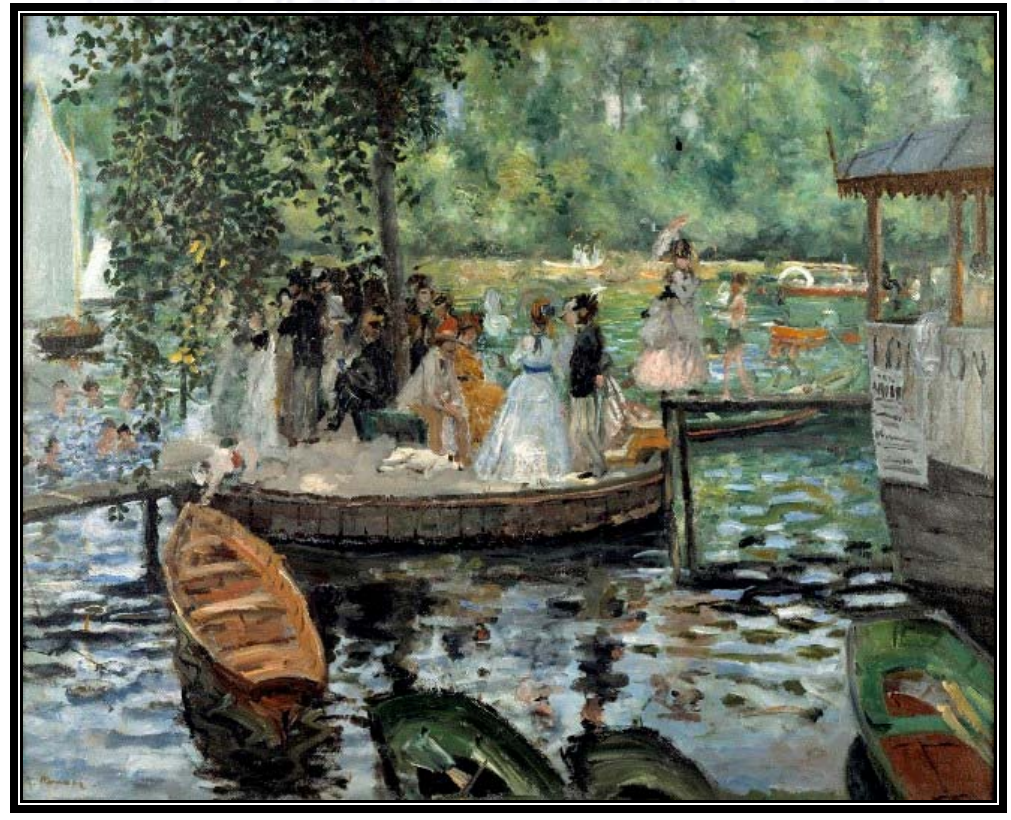

Autor: Pierre-Auguste Renoir

Obra: La Grenouillère, 1869

"La ruidosa turbulencia de una divertida multitud", es sin duda la nueva gente de la sociedad burguesa. El relator sostiene que esa manera de pintar "se adecuaba" a esa divertida multitud. Pregunto: ¿Por qué esa manera de pintar "se adecuaba" a esa "divertida multitud"? ¿Quién la adecuó? ¿Cómo? ¿Para qué? ¿Qué ganamos si se adecua? ¿Qué perdemos si no se adecua? ¿Se adecuó sola? ¿Fue una feliz coincidencia su adecuación? ¿Un milagro?

El relator nunca contesta porque no se lo pregunta. La pregunta y la respuesta es la Teoría del Carácter de Producción. Esta pregunta: ¿Cual es el origen de 
la cultura del hombre? Requiere de la siguiente respuesta: Una orientación inconsciente del carácter que sirve para trabajar, el Carácter de Producción.

El estilo estético del impresionismo no sólo es la disolución de la forma, su desestabilización, el individuo liberado y autónomo orientado resulta en la libertad y autonomía del color. Así tenemos que "...los impresionistas liberaron el color hasta conducirlo a la autonomía". (19)

Liberado y autónomo el color orientado se torna puro, fuerte, espontáneo, libre, fresco y brillante.

En primer plano se encontraba la coloración del objeto percibido al aire libre, que se reproducía mediante manchas (taches) de colores preferiblemente puros y de fuerte luminosidad, aplicadas con gran soltura unas junto a las otras. Los pintores dejaron definitivamente de hacer distinciones de valor entre un cuadro acabado y un mero esbozo. Por el contrario, consideraban mejores y más verdaderos los esbozos, gracias a su espontaneidad y frescura. A través de testimonios posteriores, sabemos que los artistas sólo querían ser un ojo, es decir, solamente percibir y no reflexionar. (20)

\section{La explicación de la psicología de los personajes de la pintura del impresionismo}

¿Cómo son los personajes de la pintura del impresionismo? ¿Cómo se comportan? ¿Qué relación tienen entre ellos, con el entorno, con los objetos, con el observador? ¿Cuál es su explicación en el contexto de la teoría del Carácter de Producción?

Los personajes de la pintura del impresionismo son alegres viven en armonía y felicidad porque es la orientación de una persona, ahora individuo liberado de los yugos del feudalismo. Al respecto, con relación a la obra de Monet, veremos que... "La representación de impresiones producidas por la naturaleza durante sus paseos o de la felicidad familiar en floridos jardines se adecuaba mejor a la entidad humana de Monet". (21)

Y en el mismo tono, con relación a la obra de Renoir...

Sus luminosos y desenvueltos cuadros, realizados a partir de un mundo real observado con extrema atención, caracterizan ese mundo como un lugar en el que son posibles la armonía y la felicidad. Los personajes representados llevan una vida satisfecha. (22)

...en la obra de Renoir de las postrimerías de los años setenta aparecen reiteradamente cuadros que representan charlas amigables o amorosas y aspectos de la vida social al aire libre. (23) (Ver pintura 11) 


\section{Pintura 11}

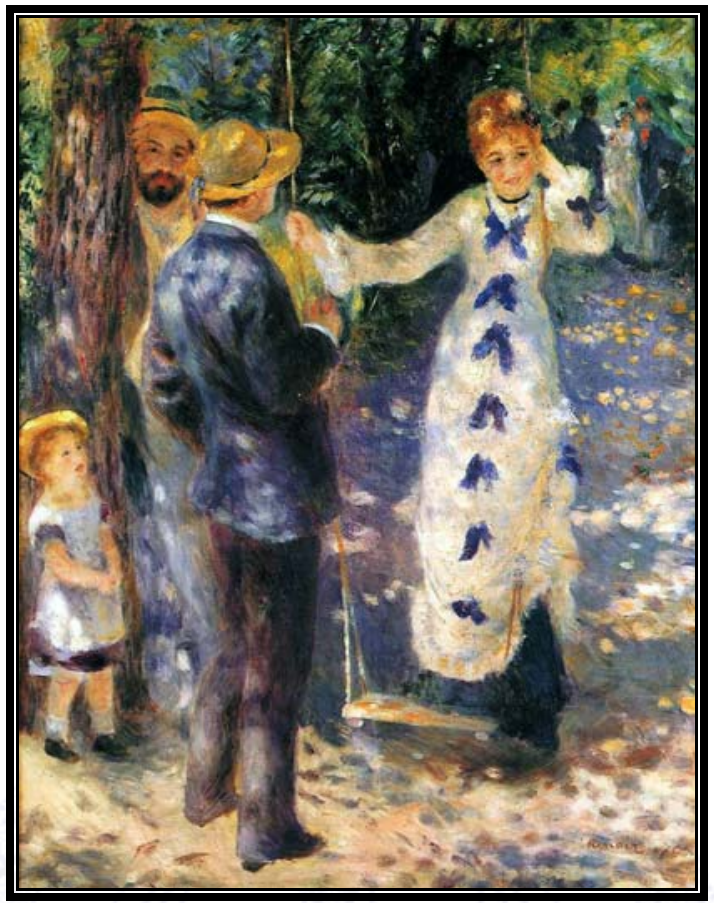

Autor: Pierre-Auguste Renoir

Obra: El Columpio, 1876

Me permito referir las siguientes ideas como conclusión al presente apartado:

Pintar de forma impresionista significa representar lo visto con los propios ojos, la realidad presente y circundante, tal como aparece ante la mirada del artista... En el centro de gravedad se encontraba la vida cotidiana, sobre todo la realidad de la propia clase social, en la medida en que era bella y alegre. Se prefería pintar el ocio en lugar del trabajo, y los paisajes, el mar y el cielo mostraban siempre su cara más placentera. Eran temas pictóricos habituales y adecuados a las exigencias del público, y por tanto vendibles. Se prestaba especial atención a los rasgos dinámicos de la realidad, en la cual se podían observar rápidos cambios, y sobre todo a las trasformaciones y movimientos, incluyendo los de la luz y los colores. (24)

Pero el asunto no es tan simple, es tan complejo como el individuo. Los impresionistas lo pintaron.

\section{A) El individuo-cosa de la pintura del impresionismo. De la alegría de la libertad a la soledad aemotiva}

El individuo liberado, orientado se vuelve cosa, solo y sin vida propia. Ya no existen los fuertes nexos colectivos y grupales del feudalismo. Lo estratifican dándole una identidad que es parte de una comunidad, estable y de por vida. De ahora en adelante probaría su suerte sólo con su fuerza de trabajo y dinero en el mercado capitalista, como una mercancía más, como cosa, solo y sin vida propia (Nota 2). 
Los orientados impresionistas lo vieron, lo sintieron y lo pintaron. Analicemos el cuadro Reunión de familia, de Bazille, "obra maestra de la burguesía". (25) (Ver pintura 12)

\section{Pintura 12}

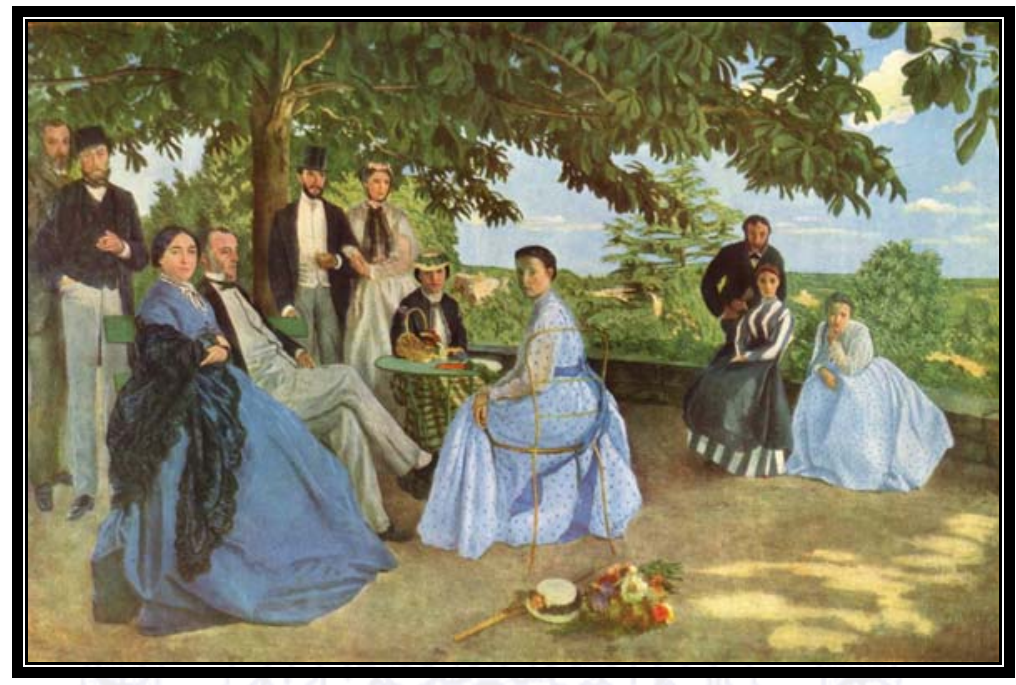

Autor: Frederic Bazille

Obra: Reunión de familia, 1867

...merecería un profundo análisis cultural y sociológico basado en la postura de los personajes. Nada ocurre entre ellos, dibujados con precisión y pintados de forma fría y plana. Ni siquiera sus miradas se ponen en contacto. Aquí no se ha plasmado una escena observada de manera desapercibida: el artista (así como el espectador) y los representados se observan fijamente unos a otros con un impasible distanciamiento. (26)

Al individuo, cosa del mercado capitalista, también lo vio Degas:

El artista plasmó el comportamiento cotidiano de esa sociedad en algunos lienzos de gran penetración psicológica, donde refleja situaciones de crisis entre seres humanos que actúan calladamente, ignorando a los demás. (27)

Por ejemplo, su cuadro La Place de la Concorde (Ver pintura 13) “...es una de esas extrañas representaciones de paseantes y familias en las cuales los personajes se ignoran mutuamente". (28) 
Pintura 13

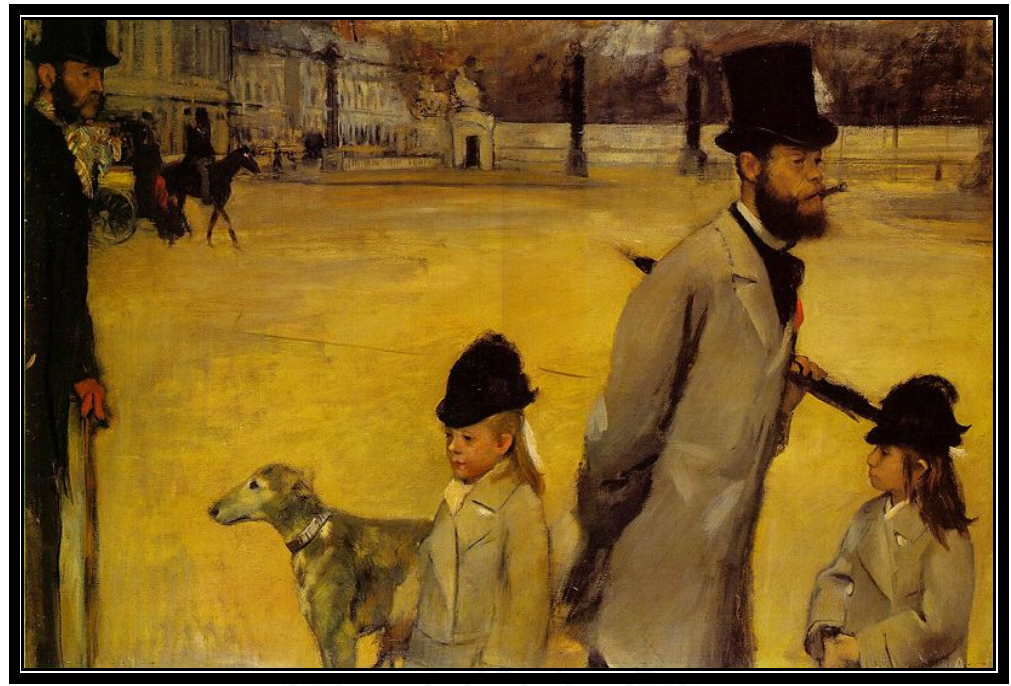

Autor: Edgar Degas

Obra: La Place de la Concorde, 1876

También Manet vio al individuo cosa, por ejemplo en su cuadro Nana. (Ver pintura 14)

Manet opera por medio de motivos y estructuras que reflejan distanciamiento y amistad fría y objetiva, seducción sensual e intangibilidad del personaje central, convertido simultáneamente en figura del culto y mercancía. (29)

Pintura 14

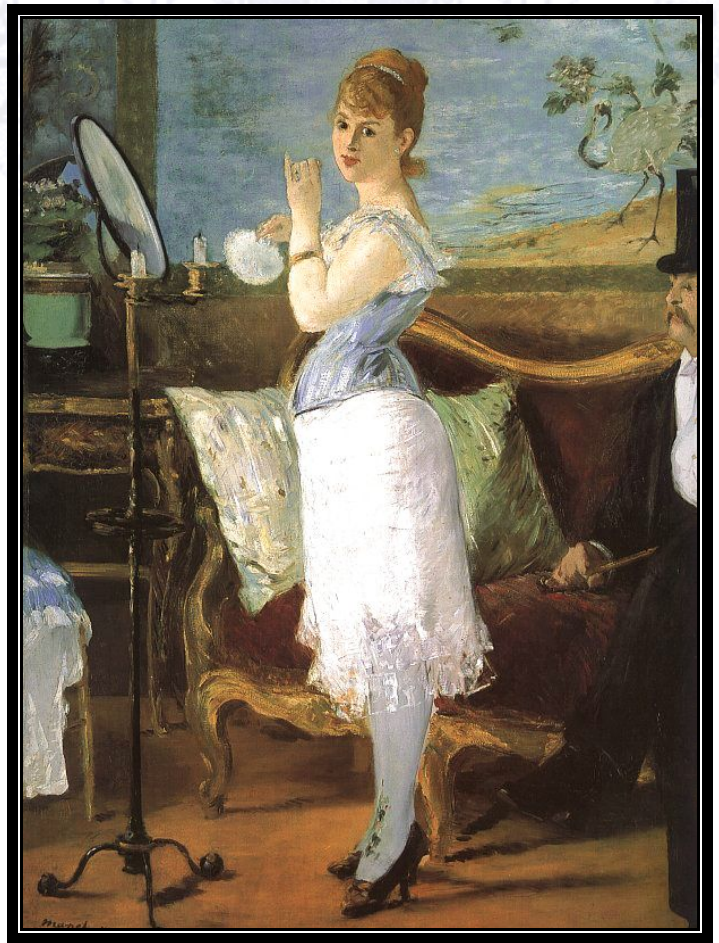

Autor: Eduard Manet

Obra: Nana, 1877 
Que el individuo se equipare a la cosa en el mercado capitalista por el carácter de producción (Nota 2) no es una interesante ocurrencia del que escribe. También el impresionista Edgar Degas refiere el individuo cosa aemotivo, a quien ve con "valor equivalente", al igual que la cosa, así lo pinta según la reseña de los críticos en su cuadro Mujer con crisantemos (Ver pintura 15), cuando dice: "Los objetos percibidos, ya sean personas, plantas, guantes o garrafas, tienen un valor equivalente". (30)

\section{Pintura 15}

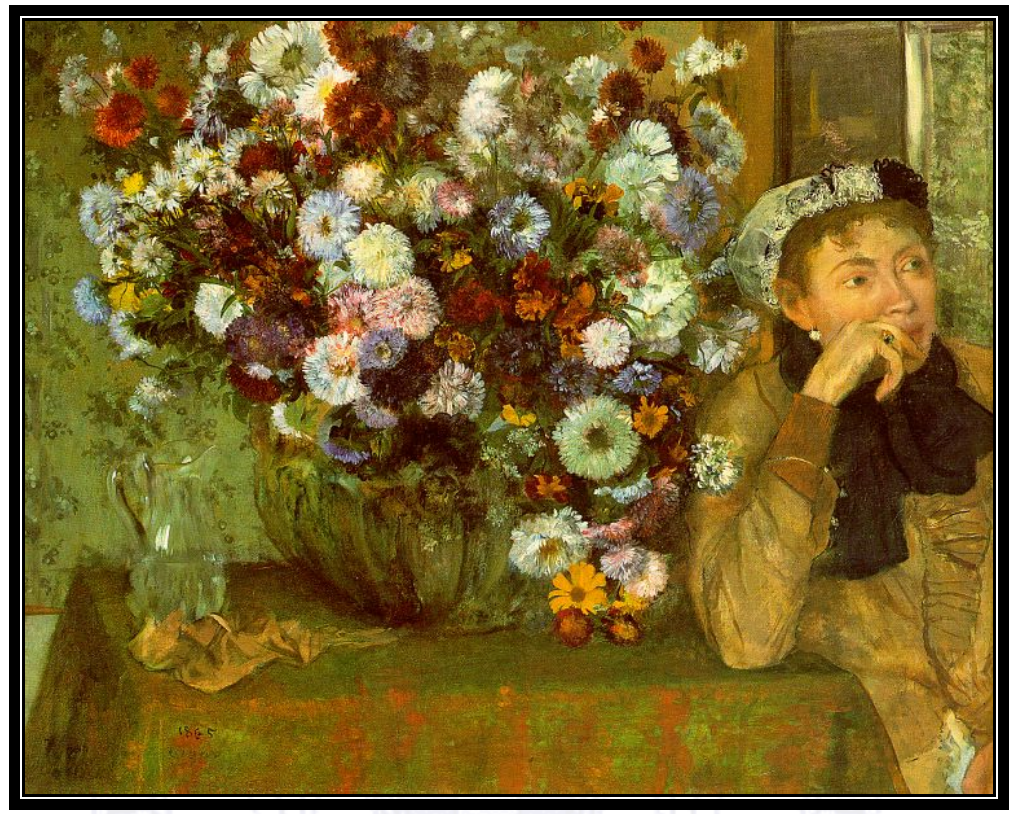

Autor: Edgar Degas

Obra: Mujer con crisantemos, 1865

\section{B) La homogeneidad de las personas. De la libertad a la igualdad}

El mercado capitalista nos vuelve homogéneos, así nos orienta; no importan familias, edades, géneros, creencias, títulos, clases, grupos o religiones, lo que importa es el dinero y la fuerza de trabajo que todos podemos detentar y con igual valor. El dinero capitalista vale lo mismo para quien lo porte en la misma cuantía, la fuerza de trabajo como mercancía del mercado capitalista se mide en tiempo-hombre. Los impresionistas orientados lo vieron, lo sintieron y lo dejaron en sus lienzos para la posteridad. Con relación al cuadro La familia Bellelli, de Degas y la igualdad en el entorno familiar, tenemos lo siguiente:

Por aquel entonces era inconcebible ubicar al margen al "pater familias" y socavar la acostumbrada severidad de un retrato de familia mediante unas posturas naturales y sin afectación. Degas lesionaba así los rasgos típicos de ese género. (31) (Ver pintura 16) 
Pintura 16

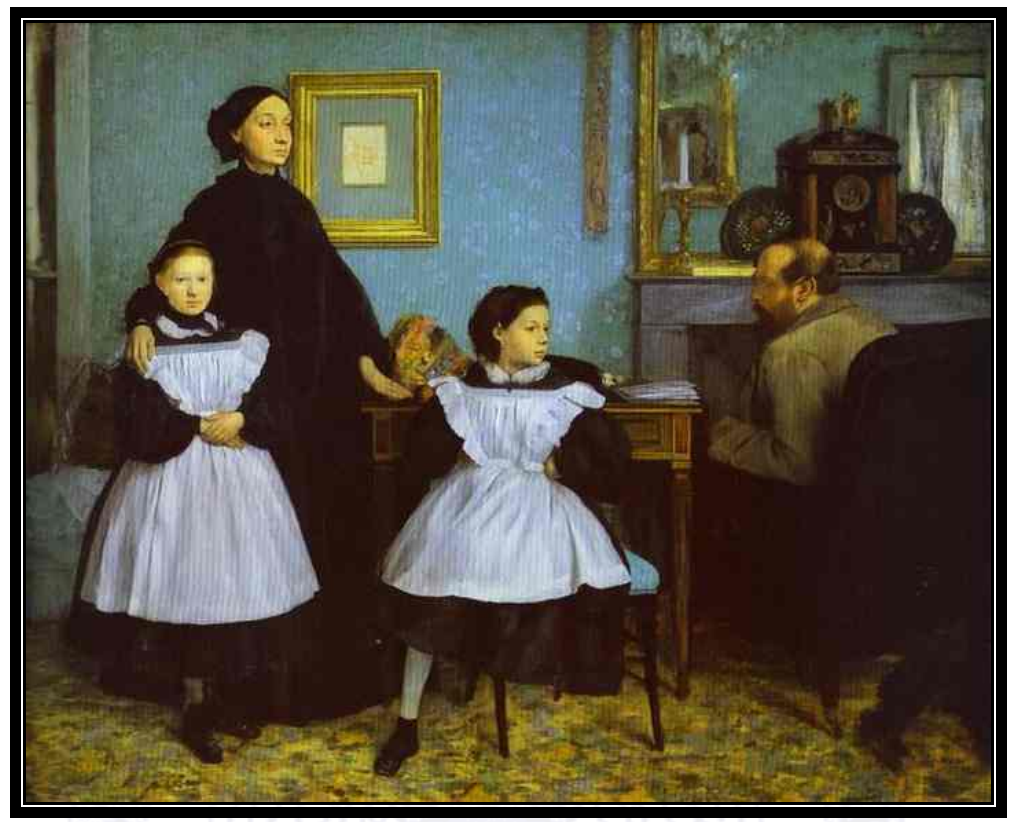

Autor: Edgar Degas

Obra: La familia Belleli, 1858-60

Y con relación al cuadro El almuerzo sobre la hierba, de Manet (Pintura 9), y la igualdad de géneros:

...sobre la situación de la cultura en aquella época. Manet lo capta de una manera objetiva, sin juicios de valores morales. La visión del autor coincide con la impasible mirada que nos dirige la desnuda Victorino. Entre los hombres -tal vez pintores- y sus amigas temporarias -tal vez modelos- [...] Sus relaciones no son emocionales, sino predominantemente prácticas y económicas. No se intercambian miradas, y los clásicos gestos coloquiales de los hombres, tendidos en actitud negligente no alcanzan a la mujer, que irradia seguridad en sí misma desde el aislamiento de su composición formal. (32)

La historia documenta que cuando nace el mercado capitalista también nace junto a otros movimientos de la sociedad moderna el movimiento feminista (Nota 2). La razón es el Carácter de Producción, una orientación inconsciente del carácter. Manet lo pintó "sin juicios de valores morales" en El almuerzo sobre la hierba, en la "impasible mirada que nos dirige la desnuda Victorino": la mujer "irradia seguridad en sí misma desde el aislamiento de su composición formal", en igualdad con el hombre. "Sus relaciones no son emocionales, sino predominantemente prácticas y económicas". La mirada autosuficiente dirigida al espectador de la desnuda Victorino preludiaba el nacimiento de los movimientos feministas y libertarios de género que después se extendieron por todo el mundo. Manet lo dejó en su obra maestra, considerada la primera pintura impresionista, y también se lo debemos al capital. 


\section{La explicación de la subjetividad de la pintura del impresionismo. De la libertad a la individualidad}

Rotos los nexos estratificados, comunitarios y estables del modo de producción feudal, la persona del mercado capitalista, ahora individuo liberado, se vuelve única. Orientada construye su mundo irrepetible como nunca antes en la historia, el mundo lo crea irrepetible como nunca en la historia del hombre, así lo provoca la oferta y la demanda del libre mercado, así lo demanda orientado el mercado del arte. Nacía el "arte por el arte", así lo interpreta el pintor impresionista y lo pinta.

El impresionismo representó el nacimiento del arte subjetivo. No era el qué del motivo, sino el cómo de su plasmación, lo que decidía la importancia y el valor de un cuadro. "Yo pinto lo que veo y no lo que otros acceden a ver", dijo el joven Manet cuando aún era un alumno del taller de Couture. Lo que contaba ya no era la individualidad ni la originalidad del tema, sino la personalidad del artista que la reproducía, con su propio estilo, único y específico. Un retrato de Manet, dijo el escritor Andre Malraux, contenía más del pintor que de la persona retratada. (33)

Con el impresionismo nace la expresión subjetiva y con ella la modernidad en el arte:

...tanto el acto de pintar como la obra de arte en calidad de vestigio duradero, adquieren valores espirituales autónomos, con independencia de la calidad reproductiva del cuadro. Con esa autonomía del trabajo personal ganaba nuevamente terreno el concepto del arte por el arte, que había sido desterrado durante largo tiempo. Se imponía cada vez más el criterio de que se pintaba porque se quería y se podía pintar. El sentido y el valor cultural de un cuadro reposaban en el mero hecho de que era un cuadro, y no otra cosa. (34)

Hagamos una recapitulación: No obstante puede surgir todavía una duda: ¿Cómo compruebas tus dichos?, dirá el crítico. La teoría del Carácter de Producción explica la pintura del Impresionismo. Al no haber otra explicación de ese sector de la realidad, se convierte en la explicación válida, en espera de que llegue otra teoría que, en todo caso, explique mejor el fenómeno. O bueno: ¿qué marco teórico propones para explicar la pintura del impresionismo? $\mathrm{O}$ ¿no tiene explicación? ¿Cómo surge? ¿Es incausado? ¿Fue el producto fortuito de la buena ocurrencia de un nutrido grupo de pintores talentosos? ¿Milagrosamente coincidieron en sus aspiraciones estéticas? ¿Fue fortuito que haya tenido aceptación entre la gente de su tiempo, también milagrosamente con las mismas características psicológicas de sus creadores? ¿El impresionismo nace ante el olvido del negro? Sin el capitalismo como creador de motivaciones inconscientes de la conducta... ¿hubiera nacido el impresionismo? ¿Hubieran vibrado los colores impresionistas? ¿Qué hubiera sido del impresionismo en el caso de que no hubiera surgido el capitalismo? ¿Hubiera gustado? ¿Conoceríamos sus lienzos? ¿Éstos se habrían perdido en alguna bodega?

¿Es casual que siendo París el centro político y económico de su tiempo, también lo era del arte universal? Ahora lo es Nueva York. ¿Es casual? ¿Es casual que en los países donde incipiente nace el capitalismo también nace el 
impresionismo? ¿Si el impresionismo se adecua a ese modelo socioeconómico? ¿Por qué se adecua? ¿Qué significa con exactitud su adecuación? ¿Merece una explicación? ¿Tiene explicación? ¿Debemos renunciar a la posible explicación del fenómeno? ¿El presente artículo es la explicación a la pintura del impresionismo? ¿El Carácter de Producción es la explicación a la cultura del hombre?

Las motivaciones inconscientes del carácter que detallo en el presente origen de la pintura del impresionismo son reales. Me baso en el Carácter de Producción, su origen; en la auto-sustentabilidad, lógica de este discurso, y en el Principio del continuo motivación-conducta, que proviene a su vez de la misma teoría. Éste sostiene que existe la motivación cuando deviene conducta (Nota 3).

La conducta de los pintores impresionistas, por ende la motivación, quedó plasmada para la posteridad en los lienzos que forman la historia de su pintura. Ahora bien, la teoría del Carácter de Producción, y las derivadas de ella, la Teoría de la Orientación (Nota 4) y el Principio del continuo motivaciónconducta, descansan en la cotidianidad, interpretando la cultura del hombre.

\section{La explicación de los movimientos postimpresionista y neoimpresionista}

Estos movimientos, refiere la historia del arte, son reacciones al impresionismo, de lo contrario no se denotarían así. ¿Qué sucedió en la economía después de las olas? ¿Que sucedió después de que, de forma incipiente, nació en Europa el capitalismo? ¿Qué motivó el nacimiento de estos movimientos artísticos? ¿Cómo se explica el neoimpresionismo y el postimpresionismo con el Carácter de Producción?

\section{A) El movimiento postimpresionista. De la ilusión a la desilusión. De la alegría de la libertad a la realidad del crudo mercado capitalista. De la realidad del crudo mercado capitalista, al refugio en la evasión de la realidad}

Liberado del feudalismo, el hombre en su reciente calidad de autónomo, de individuo, prueba su suerte en el incipiente y ahora definido libre mercado capitalista, la oferta y la demanda incontrolables lo hace sentir por primera vez impotente, solo. Las leyes impersonales de la lógica del capital lo agobian, siente miedo. El estado económico final sucede a la turbulencia de la ruptura, la alegría da paso a la melancolía, al desencanto, al dolor y con ello al deseo de fuga.

El capitalismo, en el postimpresionismo (también el neoimpresionismo en menor medida y con un importante matiz), nos regala el primer movimiento estético de fuga-evasión de la modernidad en la vida del liberado, pero también frustrado individuo de la sociedad burguesa. Si el impresionismo, al ser una orientación del carácter en el contexto de la teoría del Carácter de Producción, es un movimiento ubicado en su medio, gozoso de lo real, del mercado, feliz, realista; el postimpresionismo, reacción a la reacción, orientación inconsciente, 
tiene que haber sido, si la tesis que sostengo es cierta, un movimiento de fuga, evadido de su medio, temeroso de lo real, atemorizado por el mercado, infeliz, no realista. Así fue.

Con relación al postimpresionismo, reacción al realismo impresionista, sabemos que...

La mayoría de los principios válidos en el impresionismo lo identifican como una consecuencia de opiniones precedentes, es decir, como un punto culminante y final. Lo que para la mayoría de los contemporáneos aparecía como un rebelde modernismo tenía en realidad estrechos contactos con las tradiciones. Actualmente, muchas personas son con razón muy sensibles al valor de ese tradicionalismo, sin ser consideradas por ello como conservadoras en sentido estricto. Sólo con el postimpresionismo se produjo una ruptura artística fundamental, cuando llego el final de la perspectiva científica y fue abandonada la profunda ligazón entre la creación artística y la reproducción de lo aparente, que imperó durante largo tiempo. (35)

Y con relación al postimpresionismo, en tanto escape-evasión...

Mientras que pocos decenios antes el objetivo de la lucha consistía en rechazar los modelos clasicistas y académicos del pasado y declararse adepto de la vida moderna, ahora se imponía el repudio del próspero capitalismo y la repugnancia ante la mayoría de los fenómenos y procesos del presente. En consecuencia aparecieron movimientos de escape y evasión. La vaga esperanza de acceder a paraísos futuros se reducía primordialmente a la búsqueda de paraísos perdidos. Tal como había ocurrido durante el romanticismo, se esperaba encontrarlos en las condiciones de vida primitivas, es decir, de los primeros orígenes, pre-burgueses y anteriores a la aparición de la máquina moderna. (36)

La búsqueda de "paraísos perdidos", como sucedió en el postimpresionismo, es una extravagante búsqueda, yo diría rara, extraña, incluso torpe, irracional, inexplicable, descontextualizada, aislada, sin ningún fundamento; si no fuera porque el hombre trabajando se orienta inconscientemente lo que fundamenta, es decir, materializa tal actitud. De no ser así la relación entre el hecho y el contexto está "perdida". El Carácter de producción es el nexo buscado en toda la historia del hombre, entre lo particular y lo general, como el torrente sanguíneo que nutre las células en el organismo humano.

Estabilizada la economía (faltaba más), también regreso la línea, una orientación inconsciente teorizada por el Carácter de Producción. Su regreso en el postimpresionismo corrobora mi postura con relación al fundamento "desestabilizado" del estilo estético de la pintura del impresionismo. De no ser así, tanto su desaparición como su regreso son un misterio inasible al entendimiento.

Así reprochan los postimpresionistas a los impresionistas, dijeron no comprender, las cualidades de la línea (Ver pintura 17):

...Confundir la línea con el color significa que no se han comprendido las cualidades de cada uno de esos medios de expresión: La línea expresa lo permanente y el color lo momentáneo. La línea es un símbolo casi abstracto que refleja el carácter del objeto, mientras que la unidad del color condiciona la atmósfera general y el mundo de los sentimientos. (37) 
Pintura 17

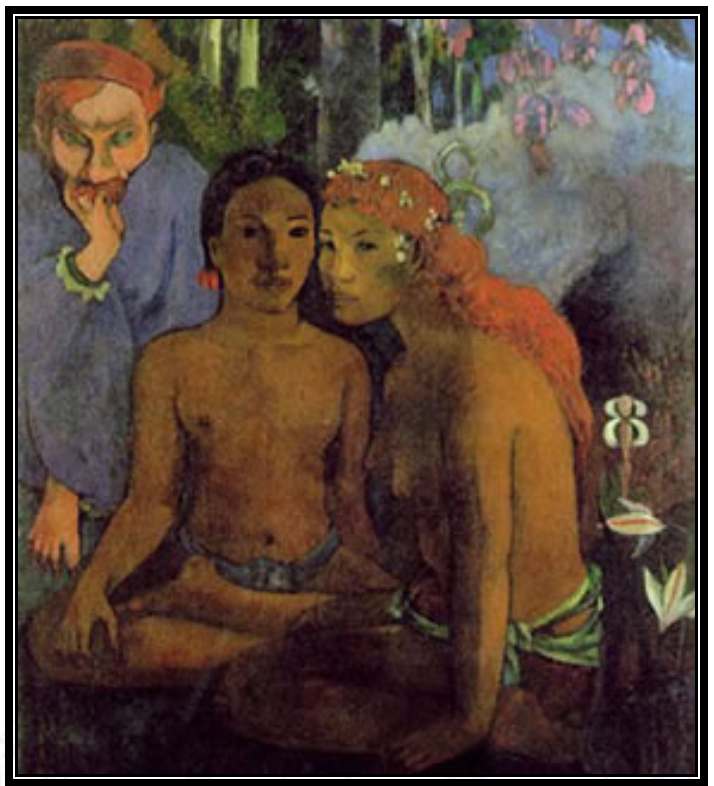

Autor: Paul Gaugin

Obra: Leyendas exóticas, 1902

\section{B) El movimiento neoimpresionista. De la realidad del crudo mercado capitalista al refugio en la neutralización de la realidad}

Estabilizada la economía, después del incipiente nacimiento del capitalismo moderno, se produce en el contexto de la teoría del Carácter de Producción la reacción inconsciente a la inicial reacción inconsciente, que en las artes plásticas no tuvo como único recurso la fuga-evasión de la realidad. Representada por el movimiento postimpresionista y, en menor medida, por el neoimpresionismo, ambos movimientos temáticamente no realistas, por tanto movimientos de evasión.

Para evitar el dolor del desencanto, el hombre orientado busca neutralizar su crudo entorno, refugiándose en lo carente de vida, lo inerte. Después del impresionismo, la alegre vitalidad inestable de lo vivo encuentra refugio desilusionado en lo muerto. El inconsciente de los pintores neoimpresionistas, simbolizado por lo mental racional, así evita el dolor del contacto con lo real, lo emotivo.

El pintor neoimpresionista, intelectualizado, tranquilizado, vuelca su interés por la ciencia, el estudio de los colores, racionaliza lo visual acoraza sus sentimientos, neutraliza sus emociones con matemáticas y leyes. El mercado capitalista, en el neoimpresionismo, nos regala el primer movimiento estético de neutralización de la realidad, de la modernidad del liberado, pero frustrado individuo de la sociedad burguesa. Así lo vivieron los pintores neoimpresionistas y con gran belleza lo pintaron.

Con relación al método neoimpresionista, Pissarro explica en una carta a Durand-Ruel el método utilizado por Seurat, el padre del movimiento, que 
consistía en "remplazar la mezcla de pigmentos por la mezcla óptica, o dicho de otra manera, la descomposición de los tonos cromáticos en sus elementos básicos" (38). Y concluyó así:

En un primer momento Seurat denominó este procedimiento con el término cromoluminiscencia, pero luego decidió adoptar el término divisionismo. Más precisas parecerían ser la denominación puntillismo empleada por Signac y la designacion de carácter mas bien historico neo-impresionismo (39).

Que el neoimpresionismo sea intelectualizado, por tanto carente de vida, neutralizador de las emociones (léase en el Carácter de Producción, sedante del desencanto, del dolor), no es otra interesante ocurrencia mía para embonar a placer la realidad con la teoría, para luego gozoso afirmar que la explico. El pintor Camile Pissarro quien representa, tanto el impresionismo como el neoimpresionismo, lo vio, lo sintió y lo escribió en la forma siguiente:

... esa llamada teoría científica... afortunadamente pude constatar que yo no era idóneo para ese arte, que despierta en mi una impresión de monotonía mortal [por el contrario, deseó] ... representar la vida y el movimiento (40).

En el arte como en la cotidianidad la mezcla de elementos es lo más común. Si mezclamos la fuga-evasión (no realismo) con la neutralización (intelectualismo/cientificismo), como sucede en el neoimpresionismo, es porque "la intención de lograr una determinada forma según severas normas interiores... logró imponerse sobre la fiel reproducción de lo percibido". (41) (Ver pintura 18)

\section{Pintura 18}

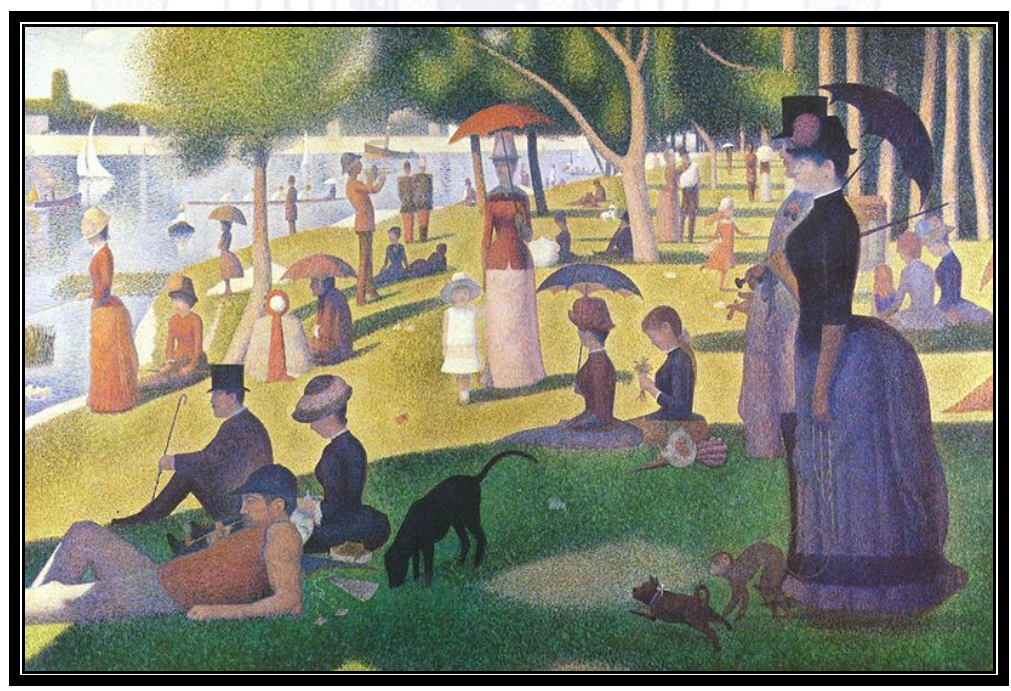

Autor: Georges Seurat

Obra: Una tarde de domingo en la isla de Grande Jatte, 1884-86 


\section{La cultura del hombre contemporáneo en el Carácter de Producción}

La teoría del Carácter de Producción explica cualquier producto cultural de la historia, incluidos los que inspirados en el capitalismo contemporáneo están creándose en algún lugar del planeta. Se está definiendo una nueva expresión cultural: una corriente musical de vanguardia, nuevas expresiones dancísticas, una corriente novedosa en lo pictórico. En algún lugar del planeta se está creando una nueva corriente pictórica a cuyo entendimiento nos podemos acercar y explicarla con la teoría propuesta, como todo producto en la historia de nuestra cultura.

El mercado capitalista te oprime. Al mismo tiempo, paradójicamente, deja espacio a tu iniciativa porque la necesita. Un hombre libre, esclavo de su libertad, enfrentado a un entorno contradictorio, cambiante, irracional, melancólico, nervioso, angustiante. El mercado capitalista es dramáticamente expresivo. ¡Es la locura! Una sensación de ahogo superado o en vías de superación, un afirmarse para no dejarse llevar o acaso intentarlo. Es el Expresionismo (Ver pintura 19), cultura del hombre moderno, su Carácter de Producción. ¿Te gusta?

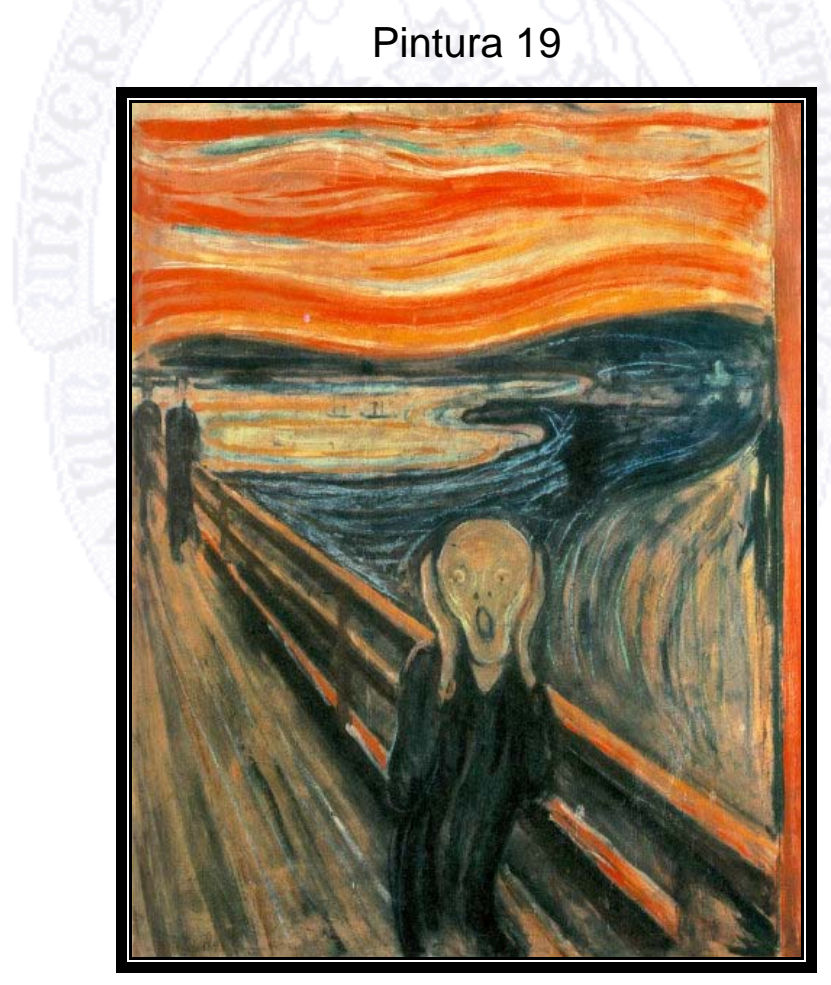

Autor: Edvard Munch

Obra: El grito, 1893

El mercado capitalista nos tiene encasillados, encerrados, prisioneros, acartonados, alienados: es la lógica del capital. ¿Qué somos? ¿Acaso angustia y soledad? ¿Qué somos? ¿Líneas? ¿Cubos? ¿Estamos carentes de curvas? ¡Estamos prisioneros! ¿Te sientes línea? ¿Cubo? ¿No te sientes así? ¿Sin Curvas? ¿Cómo te sientes? Así lo vive toda una corriente moderna de pintura que orientada, proyectada, interpreta el capitalismo contemporáneo: es el Cubismo (Ver pintura 20). ¿Te gusta? 
Pintura 20

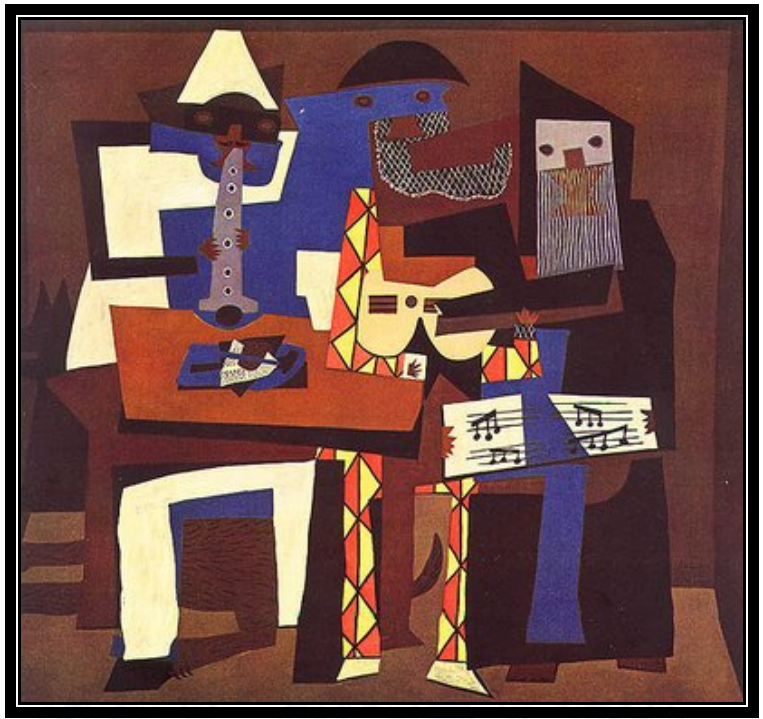

Autor: Pablo Picasso

Obra: Tres músicos, 1921

El mercado capitalista nos mueve sin percatarnos, sus tentáculos son la oferta y la demanda del libre mercado, su mounstroso cuerpo el capital que debe crecer, si no se muere. El capital se mueve, y en su movimiento nos mueve. Parece magia: ¡está vivo el capital! Es gracioso: ¡da miedo! Es el fetichismo de la mercancía. ¿Dónde quedó lo que era? Se nos perdió la realidad y con ella nuestro entorno terrenal. ¡Lo muerto vive! ¡Se ve fantástico! ¿No vivimos una especie de sueño? ¿Es un gracioso sueño? ¡Una Pesadilla! ¡Es el mercado capitalista! ¿Es un sueño el mercado capitalista, el capital? Es el Surrealismo (Ver pintura 21) un liberador deseo de fuga, inspirado en lo onírico e irracional del capital, identificación con la realidad negándola, pintura no realista inspirada en la realidad, fuga identificada, cultura del hombre en el Carácter de Producción. ¿Te gusta? 


\section{Pintura 21}

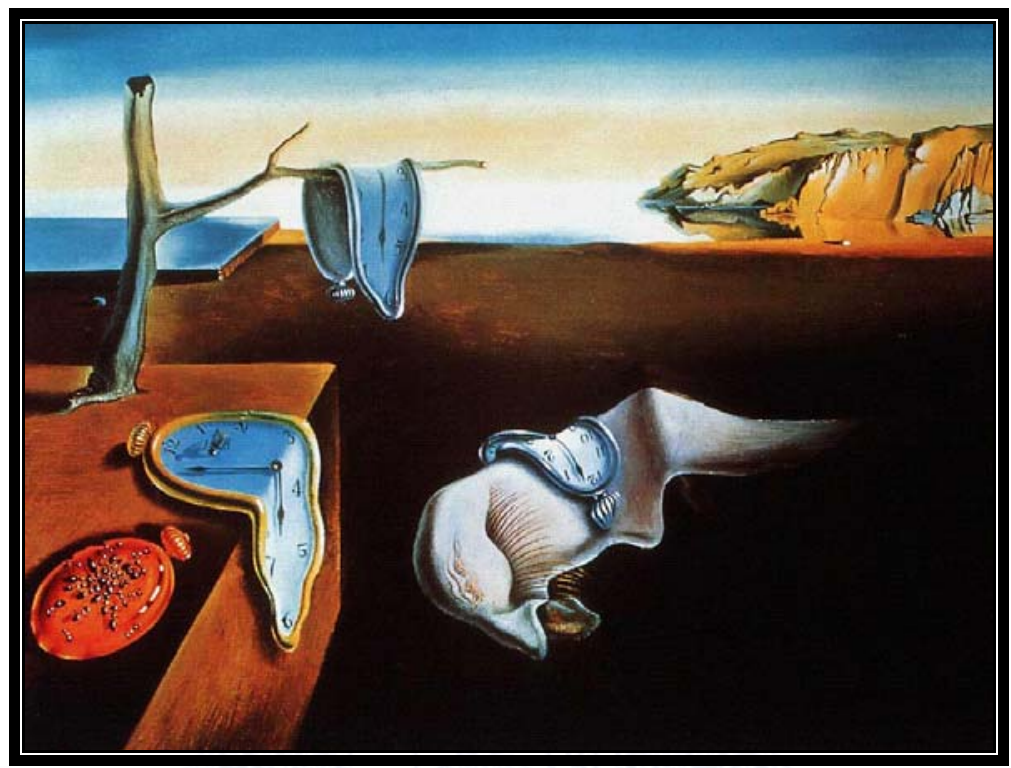

Autor: Salvador Dalí

Obra: La persistencia de la memoria (Relojes blandos), 1931

¿Sientes cómo el mercado capitalista nos borra la posibilidad de decidir? La economía burguesa del capital nos mete en un torbellino en el cual parecemos manchas o rayones; cuando mucho, figuras sin sentido. El capital despersonaliza, distorsiona, anula. ¿Qué somos en el mercado capitalista? ¿Tú te sientes algo en la economía del capital? El mercado nos borra ¿Qué somos? Es la Pintura Abstracta (Ver pintura 22), expresión característica del carácter inconsciente del hombre contemporáneo ¿Te gusta? ¿Te identificas con ella? ¿Te sientes arrojado en la nada, anulado, esfumado, como mancha?

\section{Pintura 22}

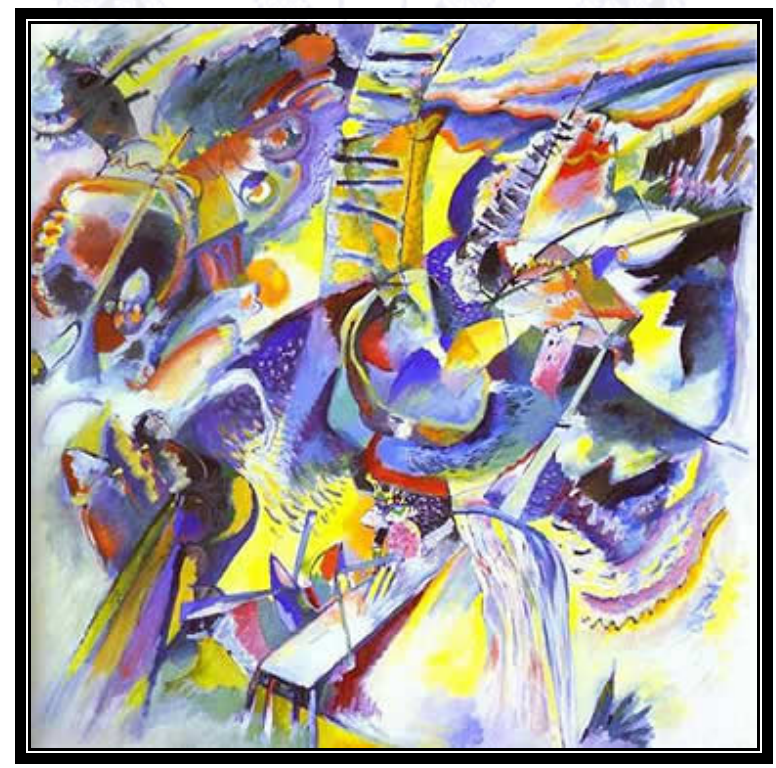

Autor: Vasily Kandinsky Obra: Improvisación, 1914. 
El incierto mercado capitalista agrede, oprime, angustia. El hombre moderno lo pinta en su deseo de neutralizar su entorno. Nos vuelve cosas enajenadas, mercancías, zombis entre la riqueza del mercado (un pobre bienestar), alegres cuando estamos de compras. El hombre moderno lo pinta (se pinta) en su deseo de neutralizar su entorno, pinta lo banal, trivial, así evita el dolor del contacto con lo real (su realidad), un bienestar ficticio. Es el Pop Art (Ver pintura, collage, 23), expresión orientada actual del hombre moderno que en el bienestar neutraliza y trivializa el dolor. ¿Te gusta?

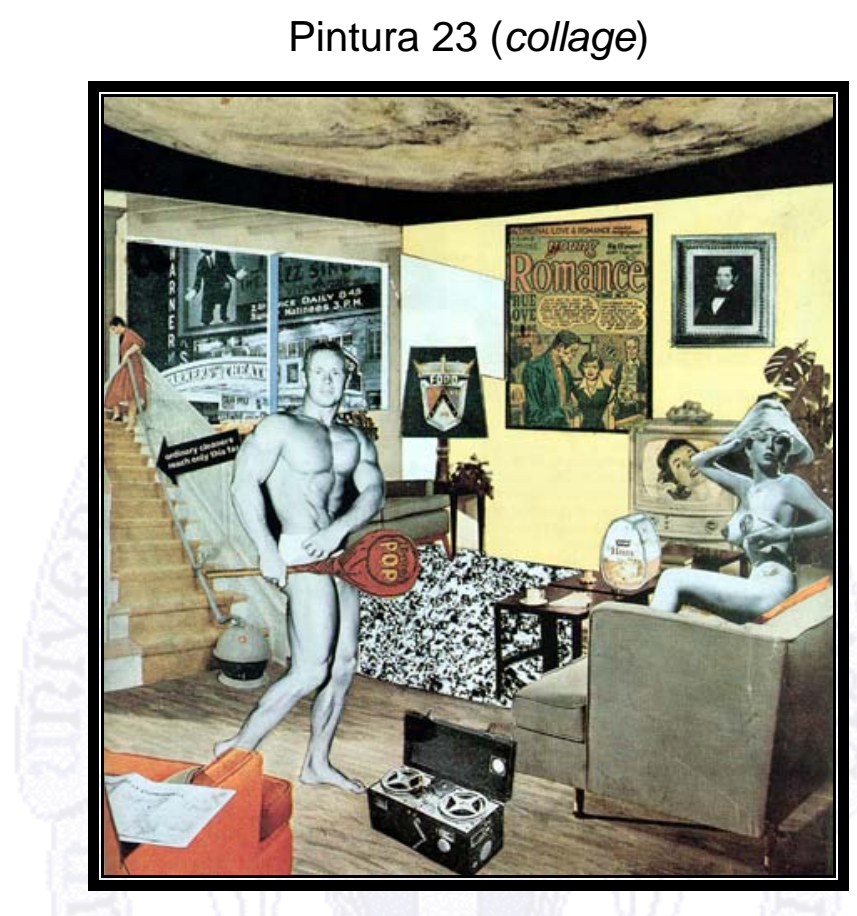

Autor: Richard Hamilton

Obra: ¿Y qué es lo que hace a los hogares de hoy en día tan diferentes, tan atractivos?, 1956

\section{Conclusión}

En la Teoría del Carácter de Producción el hombre no es un reflejo pasivo y mecánico de la realidad, algunos aspectos del capitalismo sensibilizan a unos más que otros aspectos del mismo libre mercado o interpretan los mismos aspectos de distinta manera en el crisol de su sensibilidad e individualidad. El hombre es un ser libre que interpreta libremente la realidad, su realidad.

El presente artículo ("La explicación a la pintura del impresionismo"), explica el impresionismo, tiende nexos causales entre dicho movimiento artístico y el entorno económico que lo motivó. Encontramos los siguientes aspectos: en su concreción, los lienzos impresionistas, hecho tangible de la realidad; en su temporalidad, la cronología del inicio del capitalismo; en su espacialidad, el entorno europeo más desarrollado; en su generalidad, el movimiento artístico en su totalidad; en su especificidad, las características particulares del lienzo impresionista, como lo son su temática, su estilo estético, la psicología de sus personajes y la subjetividad del movimiento. 
El postimpresionismo y el neoimpresionismo, al contrario del impresionismo, al ser movimientos temáticamente no realistas, son de evasión/fuga. El postimpresionismo caracterizado por el componente fuga, el neoimpresionismo por el de neutralización. La fórmula emotiva del impresionismo en tanto estilotemática (cómo lo pintan/qué pintan) es inestabilidad-alegría; la del postimpresionismo es estabilidad-desencanto/evasión/fuga; la del neoimpresionismo es estabilidad/neutralización-desencanto/evasión.

En el contexto de la pintura, desde la mayor generalidad abstractiva, permítanme la expresión, el incipiente mercado capitalista primero nos ubica, es el realismo; luego nos alegra (se cimbra), es el impresionismo; luego nos desencanta (se estabiliza), es el postimpresionismo y neoimpresionismo; luego nos angustia, es el expresionismo; luego nos encierra, es el cubismo; luego nos evade/fuga, es el surrealismo; luego nos borra/anula, es el arte abstracto; luego nos neutraliza, es el pop-art. Así tenía que haber sido y así fue, la historia ya está escrita, es el mejor sustento de mi palabra.

La lógica de la pintura moderna responde a una lógica emotiva, la del Carácter de Producción: ubicación, alegría/desestabilización, desencanto/estabilización, angustia, encierro, evasión/fuga, anulación, neutralización. Cuyas contenidos emotivos corresponden a realismo, impresionismo, postimpresionismo y neoimpresionismo, expresionismo, cubismo, surrealismo, pintura abstracta y pop-art.

Alguien finalmente argumentará que vive el mercado capitalista, pero éste no lo ha motivado a pintar en ninguna de las corrientes descritas (impresionismo, postimpresionismo o neoimpresionismo, etc.), y si así es no forma parte de la historia de estos movimientos. Incluso el argumento con derecho, lógicamente es extensivo a contemporáneos a estas corrientes, objeto ellos de los mismos estímulos que los creadores de la pintura del impresionismo. Después sostendrá la falsedad de mi tesis, el Carácter de Producción, al no ser coherente con el Principio Universal de Equivalencia.

Fueron muchas condiciones las que le hicieron surgir: la economía europea, los inicios del fenómeno capitalista francés, diversas condiciones estéticas que la precedieron o que la influenciaron, la individualidad irreducible de la vida de cada pintor (que también es estímulo- orientación). Y bueno, también con respeto, respondo: no eres Frederic Bazille, Jean Bèraud, Eugène-Louis Boudin, Gustave Caillebotte, Adolphe-Felix Cals, Paul Cezanne, Edgar Degas, Jean-Louis Forain, Paul Gaugin, Vincent van Gogth, Eva Gonzalès, Armand Guillaumin, Henri Le Sidaner, Gustave Loiseau, Maximilien Luce, Edouard Manet, Claude Monet, Berthe Morisot, Camille Pissarro, Jean-Francois Raffaelli, Odilon Redon, Pierre-Auguste Renoir, Georges Seurat, Paul Signac, Alfred Sisley, James Tissot, Henri de Toulouse-Lautrec. Su obra es mucho más que mi dicho, su sensibilidad irredactable, el arte no es su discurso, ellos interpretaron genialmente en sus lienzos su entorno. En su memoria la explicación a la pintura del impresionismo. 


\section{REFERENCIAS BIBLIOGRÁFICAS:}

1. BERNAL MORA, Héctor (2003). "El Carácter de Producción". En Revista Universidad de Guadalajara, Núm. 29, p. 11. México: Universidad de Guadalajara.

(Versión

electrónica

disponible

en: www.cge.udg.mx/revistaudg/rug29/opinion2.html)

2. BERNAL MORA, Héctor (2003). “El Carácter de Producción”. En Revista Universidad de Guadalajara, Núm. 29, p. 11. México: Universidad de Guadalajara.

(Versión electrónica www.cge.udg.mx/revistaudg/rug29/opinion2.html) disponible en:

3. H. FEIST, Peter (2002). "Impresionismo en Francia". En Ingo F. Walther (editor), El impresionismo Slovenia: Taschen, p. 28.

4. H. FEIST, Peter (2002). "Impresionismo en Francia". En Ingo F. Walther (editor), El impresionismo Slovenia: Taschen, p. 16.

5. H. FEIST, Peter (2002). "Impresionismo en Francia". En Ingo F. Walther (editor), El impresionismo Slovenia: Taschen, p. 20.

6. H. FEIST, Peter (2002). "Impresionismo en Francia". En Ingo F. Walther (editor), El impresionismo. Slovenia: Taschen, p. 15.

7. RUHRBERG, Karl (2001). "Pintura". En Ingo F. Walther (editor), Arte del siglo XX. España: Taschen, p. 10.

8. H. FEIST, Peter (2002). "Impresionismo en Francia". En Ingo F. Walther (editor), El impresionismo. Slovenia: Taschen, p. 7.

9. RUHRBERG, Karl (2001). "Pintura". En Ingo F. Walther (editor), Arte del siglo XX. España: Taschen, p. 10.

10. H. FEIST, Peter (2002). "Impresionismo en Francia". En Ingo F. Walther (editor), El impresionismo. Slovenia: Taschen, p. 129.

11. ZOLA, Emile (1986). La Curée. París: p. 256.

12. H. FEIST, Peter (2002). "Impresionismo en Francia". En Ingo F. Walther (editor), El impresionismo. Slovenia: Taschen, p. 125.

13. H. FEIST, Peter (2002). "Impresionismo en Francia". En Ingo F. Walther (editor), El impresionismo. Slovenia: Taschen, p. 130.

14. H. FEIST, Peter (2002). "Impresionismo en Francia". En Ingo F. Walther (editor), El impresionismo. Slovenia: Taschen, p. 40.

15. H. FEIST, Peter (2002). "Impresionismo en Francia". En Ingo F. Walther (editor), El impresionismo. Slovenia: Taschen, p. 80.

16. RUHRBERG, Karl (2001). "Pintura". En Ingo F. Walther (editor), Arte del siglo $X X$. España: Taschen, p. 9.

17. RUHRBERG, Karl (2001). "Pintura". En Ingo F. Walther (editor), Arte del siglo $X X$. España: Taschen, p. 10.

18. H. FEIST, Peter (2002). "Impresionismo en Francia". En Ingo F. Walther (editor), El impresionismo. Slovenia: Taschen, p. 90. 
19. RUHRBERG, Karl (2001). "Pintura". En Ingo F. Walther (editor), Arte del siglo $X X$. España: Taschen, p. 10.

20. H. FEIST, Peter (2002). "Impresionismo en Francia". En Ingo F. Walther (editor), El impresionismo. Slovenia: Taschen, p. 145.

21. H. FEIST, Peter (2002). "Impresionismo en Francia". En Ingo F. Walther (editor), El impresionismo. Slovenia: Taschen, p. 152.

22. H. FEIST, Peter (2002). "Impresionismo en Francia". En Ingo F. Walther (editor), El impresionismo. Slovenia: Taschen, pp. 152-154.

23. H. FEIST, Peter (2002). "Impresionismo en Francia". En Ingo F. Walther (editor), El impresionismo. Slovenia: Taschen, p. 159.

24. H. FEIST, Peter (2002). "Impresionismo en Francia". En Ingo F. Walther (editor), El impresionismo. Slovenia: Taschen, p. 97.

25. DAULTE, F. (1952). Frederic Bazille et son temps. Ginebra: p. 135.

26. H. FEIST, Peter (2002). "Impresionismo en Francia". En Ingo F. Walther (editor), El impresionismo. Slovenia: Taschen, p. 86.

27. H. FEIST, Peter (2002). "Impresionismo en Francia". En Ingo F. Walther (editor), El impresionismo. Slovenia: Taschen, p. 122.

28. H. FEIST, Peter (2002). "Impresionismo en Francia". En Ingo F. Walther (editor), El impresionismo. Slovenia: Taschen, p. 180.

29. H. FEIST, Peter (2002). "Impresionismo en Francia". En Ingo F. Walther (editor), El impresionismo. Slovenia: Taschen, p. 167.

30. H. FEIST, Peter (2002). "Impresionismo en Francia". En Ingo F. Walther (editor), El impresionismo. Slovenia: Taschen, p. 80.

31. H. FEIST, Peter (2002). "Impresionismo en Francia". En Ingo F. Walther (editor), El impresionismo. Slovenia: Taschen, p. 47.

32. H. FEIST, Peter (2002). "Impresionismo en Francia". En Ingo F. Walther (editor), El impresionismo. Slovenia: Taschen, p. 64.

33. RUHRBERG, Karl (2001). "Pintura". En Ingo F. Walther (editor), Arte del siglo $X X$. España: Taschen, pp. 10-11.

34. H. FEIST, Peter (2002). "Impresionismo en Francia". En Ingo F. Walther (editor), El impresionismo. Slovenia: Taschen, p. 99.

35. H. FEIST, Peter (2002). "Impresionismo en Francia". En Ingo F. Walther (editor), El impresionismo. Slovenia: Taschen, pp. 11-12.

36. H. FEIST, Peter (2002). "Impresionismo en Francia". En Ingo F. Walther (editor), El impresionismo. Slovenia: Taschen, pp. 268-276.

37. Rewald, J. (1961) Le Post-impressionnisme. De van Gogh à Gaugin. París: p. 98.

38. Citado por H. FEIST, Peter (2002). "Impresionismo en Francia". En Ingo F. Walther (editor), El impresionismo. Slovenia: Taschen, p. 280.

39. H. FEIST, Peter (2002). "Impresionismo en Francia". En Ingo F. Walther (editor), El impresionismo. Slovenia: Taschen, p. 280. 
40. J. Rewald. Le Post-impressionnisme. De van Gogh à Gaugin. Paris 1961, p. 254.

41. H. FEIST, Peter (2002). "Impresionismo en Francia". En Ingo F. Walther (editor), El impresionismo. Slovenia: Taschen, p. 282.

\section{BIBLIOGRAFÍA COMPLEMENTARIA:}

1. BERNAL MORA, Héctor (2010). "La propiedad privada, la monogamia, el patriarcado, la esclavitud y el Carácter de Producción". En Nómadas. Revista Critica de Ciencias Sociales y Jurídicas, Núm. 25 (Enero-Julio). España: Universidad Complutense de Madrid.

(Versión electrónica disponible en: http://www.ucm.es/info/nomadas/25/hectorbernal.pdf)

2. BERNAL MORA, Héctor (2011). "La Filosofía Política Sintética del Carácter de Producción". En Nómadas. Revista Critica de Ciencias Sociales y Jurídicas, Núm. 29 (Enero-Julio). España: Universidad Complutense de Madrid.

(Versión electrónica disponible en: http://www.ucm.es/info/nomadas/29/hectorbernal.pdf)

\section{NOTAS:}

1. Édouard Manet, considerado el primer impresionista, mostró cómo se podían obtener sutiles representaciones de luz por la yuxtaposición de colores fuertes y contrastados. Su cuadro El almuerzo sobre la hierba (1863), expuesto en el "Salón de los Rechazados" (Salón des Refusés), organizado como una oposición a las exposiciones oficiales en el Salón de la Academia, señaló el comienzo de una nueva era en el arte.

2. Desarrollo la idea en el artículo "La mercancía y la psicología del hombre moderno", publicado por la revista Anales de Psiquiatría, Nol. 25, Núm. 2, 2009) España: Aran Ediciones. Disponible en www.grupoaran.com

3. Desarrollo la idea en el artículo "Lo consciente e inconsciente en el Carácter de Producción, el principio del continuo motivación-conducta. La refutación del esquema Freudiano". Archivos de Ciencia. Revista en Ciencias de la Salud. (Vol. 1, Núm. 2, 2009) México: Universidad de Guadalajara, Centro Universitario de Ciencias de la Salud, OPD Hospital Civil de Guadalajara.

4. Desarrollo la idea en el artículo: "El Carácter de Producción y la síntesis del conductismo, el psicoanálisis, la psicología humanista-existencial y cognitiva", publicado por la revista Anales de Psiquiatría (Vol. 22, Núm. 7, 2006) Disponible en: www.grupoaran.com_ 


\section{FUENTES DE IMÁGENES:}

1. http://upload.wikimedia.org/wikipedia/commons/5/5c/Claude_Monet $\% 2 \mathrm{C}$ _Impression\%2C_soleil_levant\%2C_1872.jpg

2. http://www.historiadelarte.us/realismo/coubert-el-estudio-del-pintor.html

3. http://upload.wikimedia.org/wikipedia/commons/d/d8/Jean_Auguste_Dom inique_Ingres_005.jpg

4. http://static.letsbuyit.com/filer/images/uk/products/original/70/33/theartist-s-garden-at-vetheuil-1880-by-claude-monet.jpeg

5. http://upload.wikimedia.org/wikipedia/commons/4/4d/PierreAuguste_Renoir_007.jpg

6. http://www.malaspina.com/jpg/guillaumin.jpg

7. http://www.artchive.com/artchive/M/monet/capucine.jpg.html

8. http://i49.tinypic.com/1oneyr.jpg

9. http://upload.wikimedia.org/wikipedia/commons/f/f1/Manet\%2C_Edouard _-_Le_D\%C3\%A9jeuner_sur_1\%27Herbe_\%28The_Picnic\%29_\%281\%29.jpg

10. http://www.aidart.fr/wp-content/uploads/2009/07/Renoir-Pierre-Auguste1841-1919-La-Grenouill\%C3\%A8re.jpg

11. http://www.renoirgallery.com/paintings/large/renoir-the-swing.jpg

12. http://upload.wikimedia.org/wikipedia/commons/6/6d/Fr\%C3\%A9d\%C3\% A9ric_Bazille_001.jpg

13. http://smarthistory.org/assets/images/images/degas_place.jpg

14. http://www.ricci-art.net/img006/355.jpg

15. http://www.ricci-art.net/img002/484.jpg

16. http://en.wahooart.com/A55A04/w.nsf/OPRA/BRUE5ZKC9B/\$File/Edgar+Degas+-+The+Bellelli+Family+.JPG

17. http://www.theartwolf.com/gauguin_tropics_es.htm

18. http://arteydespues.files.wordpress.com/2009/06/800pxgeorges_seurat_031.jpg

19. http://lahistoriadeldia.files.wordpress.com/2009/05/edvard_munch_the_s cream.jpg

20. http://2.bp.blogspot.com/_Jl8BKYTmK1w/SWpBnnMLAYI/AAAAAAAAAkI /DaKVPjjX-b0/s1600-h/picasso_3musicians1921.jpg

21. http://jerkmag.files.wordpress.com/2010/02/the_persistence_of_memory _1931_salvador_dali.jpg

22. http://patry33.files.wordpress.com/2008/06/kandinsky1.jpg

23. http://htca.us.es/blogs/perezdelama/files/2008/10/hamilton.jpg 